\title{
3 The Eclogues And The Georgics
}

In the present and next chapter the focus will be on the political content of Vergil's poems, which will be read and analysed according to the scheme of analysis presented in section 1.2. Chapter 3 is divided in two parts: section 3.1 deals with the analysis of the Eclogues and 3.2 with the Georgics. Chapter 4 contains my observations and conclusions of the political content of the Aeneid.

\subsection{The Eclogues: Pastoral Poetry With Commentary On Octavian's Land Confiscations ${ }^{64}$}

\subsubsection{Introduction To The Section About The Eclogues}

The question whether Vergil expressed real personal experiences in the book of Eclogues has been explored extensively ${ }^{65}$. I will argue that the majority of the Eclogues contains the poet's commentary on two major political events: Octavian's resettlement of army veterans and the land expropriations after Philippi in 42 B.C., and their effects on the Italian countryside. These were very much part of his personal knowledge. Presumably, Vergil tapped into his own observations - and those of people he knew - of the land expropriations and its effects, using these for portraying the political and social state of affairs in Italia. This does not mean that parts of the Eclogues are Vergil's autobiography, in the sense that the poet is portraying directly his own experiences. For instance, Tityrus' visit to Rome in Ecl.1. to plead his case is not a description of the poet's own visit to the city to prevent the expropriation of his or his family's property. This visit probably never took place ${ }^{66}$. In narrating Tityrus' story in Ecl.1, Vergil does, however, use his personal experience of the expropriations. In the words of Perutelli (1995, 45): "Virgil adds a new level of reference, beyond Theocritus,

64 This section intended as a paper to be submitted to a journal was written in close cooperation with Marc van der Poel as co-author. I am grateful to Claire Weeda and Els van Thiel for their helpful comments. 65 Boucher (1966, 16-26); Clausen, 2003; Coleman (1981, 21-36); Dominik (2009, 111-132); Hermes (1980, 212-234); Nauta, 2006; Otis (1966, 109-128); Page (1960, xv-xvii); Perutelli (1995, 36-42); Tarrant (2000, 173-175); Wilkinson (1997, 24-39); Williams (1968, 303-329); Zetzel (2006, 38-52).

66 Boucher $(1966,17)$ also interprets Tityrus as a poetic persona, and not as representing Vergil himself. He states that "dans la première [Eclogue], Virgile, par l'intermédiaire de Tityre [...] témoigne de ses sentiments envers Octavien.” (Vergil, through the intermediary of Tityrus, [...] speaks in the first [Eclogue] of his views of Octavian). All renderings of French text into English are mine. Cf. Jenkyns (1998, 169-172),, I hold that Vergil was indeed "concerned for the distresses of his fellow countrymen, the Mantuans - so much is explicit and to that extent personal experience enters into his allusions to the confiscations; and of course it remains possible that he himself lost some land, possible even that Caesar restored it, or compensated him in some other way. But that is pure speculation, nothing more; Virgil does not suggest this to us, either directly or by implication." (Jenkyns, 1998, 171; my emphasis). See also the discussion of Ecl.1 in section 3.1.2. 
that to historical [but not autobiographical] events, which he transforms into a source of pathos. The confiscations of land introduce and explain suffering, sorrow and the sense of an end which in Theocritus' pastoral world was only aroused by the natural cycle of life and death." Vergil's literary debt, in his book of Eclogues, to his Hellenistic predecessors, chiefly to Theocritus, has long been recognised, and many scholars from the nineteenth century onwards have identified Vergil's Hellenistic model or models for the Eclogues. Generally, scholars have explored the subject from the perspective of literary models ${ }^{67}$. In addition to expressing his love of the Italian country, Vergil had a second objective when he wrote pastoral poems. Clausen (2003, xix-xx) hints at this when he compares Vergil with Theocritus:

In one important aspect, however, Theocritus is more strictly pastoral, more realistic - more considerate, that is, of his fiction - than Virgil: very rarely does he [Theocritus] allow an extraneous reference to obtrude, [...]. Yet these few references in Theocritus, together with his [Vergil's] own sense of the sufficiency of the country, enabled Virgil, apparently, to include a wider range of experience - politics and politicians, the ravages of civil war, religion, poetry, literary criticism - in a pastoral definition.

Scholars who explored whether Vergil expressed real personal experiences concluded that this is only the case in a limited number of Eclogues. In addition, they are divided as to which poems these experiences can be found $\mathrm{in}^{68}$. In an introduction

67 It is probable that Vergil had access to a collection of pastoral poetry by Artemidorus of Tarsus. This edition contained ten poems attributed to Theocritus (Idylls 1 and 3-11). See Clausen (2003, xx); Gow (1986, lix-lxii, esp. lx). In the case of the Eclogues Harrison (2007c, 34-74), writing about generic enrichment and/or generic departure in Vergil (and Horace), examines particularly Vergil's inspiration by Theocritus, although Harrison (2007c, 39) also points out that "often we can see a connection between generic enrichment and [reference to] political circumstances.” An anonymous reviewer of the manuscript made the comment that "the most important scholarly debates and literature" on the literary tradition are not sufficiently acknowledged in this book. I do not enter the discussion on the literary tradition on purpose, as the focus of the book is very different from most, if not all existing scholarly work. I do not examine Vergil's poetry from a literary perspective. My focus is on the functional frame - in this case his political views - which explains why the reviewer did not find a comprehensive discussion of the scholarly literature, which generally is concerned with the literary.

68 Page (1960, xv-xvii) identified Ecl.1, 6, 9 and 10 as a "group distinctly connected with the poet's personal experiences.” Boucher $(1966,17)$, who explores in detail the question whether the Eclogues were "pour les Romains de l'époque augustéenne le symbole de la poésie personelle, du refus de la vie politique" (for Romans of the Augustan age the symbol of personal poetry, of the refusal of the political life), argues that both are present. Williams $(1968,303-329)$ is ambiguous however, whether the dispossessions in the Mantua region are necessary to the interpretation of Ecl.1 (see Williams, 1968, 308) or Ecl.9. (see Williams, 1968, 321). Coleman (1981, 21-36) describes Vergil's notion of pastoral as a "synthesis of myth and reality" (see Coleman, 1981, 33). He (1981, 28) also refers to the "intrusions of real persons”, and acknowledges Vergil's personal experiences. Because Hermes, 1980 is concerned with book 4 of the Georgics, we do not know his view on all the Eclogues, as he discusses only Ecl.1 and 9 in his dissertation. However, he (Hermes, 1980, 234) states: "Deshalb geht auch die Auffassung 
to his essay about the interpretation of the tenth Eclogue, Conte (1986, 102, note 8) asserts: "I do not wish to deny completely the legitimacy of studies based on biographical or historical data, but in general one must be extremely wary, as the damage done often exceeds the benefits obtained." I trust that I will not damage Vergilian scholarship too much, when I suggest that the historical context - in which Vergil places most of his Eclogues - functions as the frame for his political opinions and cannot be ignored. In the following section (3.1.2) I argue that in the majority ( 8 of 10) of the poems - many more instances than generally recognised Vergil uses his personal knowledge and experience in order to expose the social and political situation caused by the decline of the rural order. Vergil did not describe historical events precisely, but adapted these using them as functional references. For instance, in a number of places Vergil mentions historical persons who are supposed to be actively involved in the dispossessions in his own area and specific events in his own region. Examples are: Alfenus Varus in Ecl.6.7, 6.10 and 6.12 (Vergil ingratiates himself with the land commission or with Varus, who represents the man in charge of the expropriations) and Ecl.9.26-27 (Varus is active in the Mantua region), and C. Cornelius Gallus in Ecl.6.64 (typifying Vergil's hope that someone may intervene on behalf of the suffering Mantuans) and Ecl.10 (Gallus' loss of his mistress). Specific events are referred to in Ecl.9.27-28 (Varus, spare Mantua), and in Ecl.10.47 where Vergil mentions the river Rhenus in Northern Italia. Bowersock $(1971,76)$ argued persuasively that "the scholia [Servius, Donatus and others] are worthless evidence for details of the land commission, and so is Virgil. That can only redound to the poet's credit. He has caught a mood, an atmosphere in his poems." There is no independent confirmation of their involvement and the scholiast had presumably no other source than the poems ${ }^{69}$. However, Vergil certainly

zunehmend dahin, daß auch Vergil irgendwie von den Ereignissen [the land appropriations] betroffen worden sein muß, und daß dies auch in den Eclogen zum Ausdruck kommt.” (Therefore, the opinion, that Vergil must also have been affected somehow by the events [the land appropriations], and that this also finds expression in the Eclogues, recedes progressively). All renderings of German text into English are mine. Clausen (2003, xxx, 29-30, 121-126, 236-237, 266, 289) identifies only Eclogues 1, 8, 9 and 10 as having a theme which is the result of Vergil's knowledge of the land confiscations and the ensuing social problems. In addition he discusses a bearing on contemporary political issues in Ecl.4. Wilkinson (1997, 24-39) concludes that Eclogues 1, 4, 5, 6 and 9 show Vergil's engagement with contemporary political issues. See also the discussion of the views of Servius and Donatus in Patterson (1987, 24-40), which raises similar questions, for instance: "Donatus professed uncertainty as to whether the causa of the Eclogues, which he merges with intention, was a desire to imitate Theocritus or to make a statement about the progress of civilization or, rather, to gain the indulgence of Caesar and the recovery of Virgil's lands” (Patterson, 1987, 31). For the supposed loss of Vergil's lands see note 66.

69 Boucher (1966, 16-26); Clausen (2003, 181); Jenkyns (1998, 170-171); Nauta (2006, 303 note 8) does not commit himself, and argues rightly: "It has been endlessly debated what may and what may not be deduced from these sources (see Horsfall (1995) 12-13, with references), and I will not presume on any 
introduced historical persons. I suggest that Varus, Pollio and Gallus represent a special kind of historical allegories symbolizing the involvement of high-ranking officials without exactly specifying who was involved where. Thus, Vergil showed the gravity of the situation. A number of passages can be interpreted as referring to events affecting people who the poet knew well (see note 66), such as Ecl.1 (Tityrus' attempt to extract a promise that his farm would not be confiscated in line 42), or Ecl.9.10 (Menalcas having won a reprieve for the family farm or other farms). There is evidence, which has so far been neglected, that Vergil referred to the new reality of the social and economic relations in the countryside through his choice of names of personae. Examples are the impertinent Thyrsis, in Ecl.7.33-34, used to refer to new arrogant landowners, or Mopsus in Eclogues 5 and 8 to refer to the new-comer soldiers, who replaced or exploited the traditional farming population. Further, the river Rhenus in Ecl.10 refers to the Reno (near Mantua), which Lycoris saw when she left Gallus, symbolising Gallus' loneliness as a result of the misfortunes of war. Finally, in Ecl.4, one can read in Vergil's preferred new constitutional order once the war was over.

Vergil was much concerned about the disappearance of farming and small holdings in Italia. In his poetry he voiced not only his concern and compassion with the suffering farmers, but also pointed out political responsibilities, often through allusions. Vergil did not hold back in naming the men whom he held responsible. In the book of Eclogues I read less praise of Octavian and his associates than for example Nauta argues ${ }^{70}$. Zetzel $(2006,50)$, in an essay about Horace's Sermones, writes that Vergil "does indeed deal with substantial problems and with the realities of Roman and Italian life in the Triumviral age.” However, his (2006, 50) conclusion that "it might be argued (as I [Zetzel] think Horace does argue), that to veil the moral and social issues under the mask of pastoral, to emphasize poetics rather than politics, to construct a smooth, elegant, and artificial world and diction [as Vergil does] is not the best way to write or to live in Rome of the mid-30s" (my emphasis) is not supported by the results of this study. Vergil is an elegant poet indeed, who, through his allusions in virtually every Eclogue, presents his political messages in a pastoral wrapping, thus subtly shrouding his viewpoint.

In a relatively recent essay (2009), entitled “Vergil's Geopolitics,” Dominik also discusses the political content of the Eclogues, particularly on the ground of a detailed examination of Ecl.171. Dominik (2009, 111) states: "My application of geopolitics

specific reconstruction of 'what really happened.”' I concur with Nauta. See also notes 81 and 91. 70 Nauta (2006, 301-332) states that Octavian is praised in Ecl.1 (2006, 305-310) and in Ecl.8 (2006, 310-316), and 'other nobles' (Pollio, Varus and Gallus) in Ecl.3, 6, 10 and 9 (2006, 316-324). I will discuss these at the appropriate places in the next section. See also note 112.

71 Dominik (2009, 115-117; 121-124; 125-126 and 127-129). Ecl. 2, 3, 6, 7, 9 and 10 are touched very briefly (2009, 129). 
involves this nexus of political and geographical factors but emphasizes specifically the political aspects that relate to, influence, weigh upon or literally cast their shadow upon a particular geographical space, in the case of Vergil, the countryside.” He (2009, 112) describes his "investigation of Vergilian geopolitics" as follows:

\begin{abstract}
Vergil uses nature to explore political issues throughout his oeuvre. Although Vergil's pastoral world has been viewed generally as a place of co-operation between man and the natural environment, the essential features of Vergil's commentary in exposing the vulnerability of the environment and its denizens to the ever-encroaching politico-military and urban worlds are not just generally sustained - despite moments of optimism and hope - but rather increase in magnitude and gravity as his narrative progresses.
\end{abstract}

According to Dominik (2009, 117-122), this is a matter not only of Vergil writing green politics, such as "rural exploitation" (2009, 117), and "destruction [of the landscape], often as the result of politico-military force and the shameless consumption of the civilized world" (2009, 119), but also of Vergil pointing out that "disintegration of the locus amoenus in the Eclogues is afforded political import not just by its manifest association to the intrusion of the urban superstructure, but especially by the personal tragedies of its inhabitants" $(2009,122)^{72}$. This study not only adds to Dominik's argument, as I am examining all Eclogues, but also has a different emphasis. I will argue that Vergil intended to deliver a political statement about the destruction of rural communities, tapping into his own knowledge and experience of the land expropriations. Martindale $(2000,107-124)$ also considers the issue of "green politics" in the Eclogues. He $(2000,118)$ contends that "at the very least one must recognise that Virgil's green spaces are somewhat 'lordly possessions.' Virgil shapes his rustic world into a form that allows him and his friends and patrons to make their own appearance there without embarrassment alongside the shepherds." In Martindale's view an important aspect of Vergil's "greenness" is his protest against the evils of the city. I intend to demonstrate that Vergil's concern went much deeper, originating in what he saw as the fundamental destruction of the way of life of the crofters and the substantial change, even loss of, traditional rural values.

Most scholars (note 68) hold the view that Ecl.1 and Ecl.9 contain elements of Vergil's personal experience and portray contemporary social and political issues, and that $E c l .2$ and Ecl.3 are bucolic poems without any reference to political topics. Concerning Ecl.1 and Ecl.9 I concur with the above views. However, I read Ecl.2 and $E c l .3$ as bucolic poems indeed, but specifically referring to the noble values of country life, which were in danger of extinction. Eclogues 1, 2, 3 and 9 will be discussed only briefly, and I will focus on six poems (Eclogues 4, 5, 6, 7, 8 and 10), offering some new arguments and interpretations.

72 Cf. Jenkyns (1998, 171); see also note 66. 


\subsubsection{The Eclogues}

In this section each Eclogue will be examined with a view to establish whether a particular poem has a political content, and its nature. This will be done not only by close reading of the poems, but also by referring to the appropriate political and social context.

The first Eclogue is written as a conversation between, on the one hand, Meliboeus, who has to leave for foreign lands as his farm has been expropriated and who wonders if he will ever return, and on the other hand Tityrus, who has the good fortune that he can remain, albeit on a small plot of infertile land. In the poem, land has been confiscated after the battle of Philippi (42 B.C.) and Vergil depicts the contrast between the two men, the unhappy Meliboeus for whom there is no future (as for many others) and the lucky Tityrus. Meliboeus asks why Tityrus has been absent and Tityrus answers that he was in Rome. Now that he is living with frugal Amaryllis, he can save enough from his property (peculium) to purchase his freedom, also he gained the ownership of the small piece of land. This is the first of several examples, where Vergil expresses his positive opinion of the role of women: frugal Amaryllis enables Tityrus to be free. Yet the threat of expropriation remains. Thus, Tityrus goes to Rome to plead his case and in Rome hic illum uidi iuuenem, Meliboee, quotannis/bis senos cui nostra dies altaria fumant (Here I saw him, Meliboeus, the youth for whom our altars smoke twelve days each year) (Ecl.1.42-43). The youth is Octavian and the altars refer to Tityrus celebrating the ruler's birthday every month ${ }^{73}$. Octavian gives Tityrus his "freedom", a promise that he can stay on his land, and tells him to continue with farming as of old: Tityrus enjoys his "double freedom" in the shade of a beech tree. That is why in lines 6-7 Tityrus cries out: O Meliboee, deus nobis haec otia fecit./ namque erit ille mihi semper deus (O Meliboeus, a god has given us this ease. For truly, to me this man shall always be a god). The interpretation that Tityrus' visit to Rome may be an allusion to Vergil's own efforts to prevent the expropriation of the family property is very likely erroneous (see note 66). In this poem, Vergil acknowledges the relative peace which Octavian has brought after Perusia (40 B.C.). However, the poem is also somewhat ambiguous. On the one hand, there is praise for Octavian as the new benign ruler, on the other there is Tityrus' visit to Rome, where his future is decided by the same benign ruler (or elite) who carried out the dispossessions after Philippi: a serious criticism of Octavian. It is most likely that the poem was written in 41 or 40 B.C., when Vergil presumably was still harbouring the memory of his negative experiences regarding Octavian's role in the land confiscations ${ }^{74}$.

73 Clausen (2003, 48); Nauta (2006, 305-310); Williams (1968, 307-312, esp. 310-311); Wissowa (1902, 157-159).

74 Nauta (2006, 309-310). Nauta's literary frame: “Tityrus had to go to Rome to meet his 'god.'. Whether Tityrus may sing or not is decided in the city, and this demonstrates that Virgil's bucolic 
The second half of the poem is about the contrast in the fortunes of the two characters. In lines 46-47, Meliboeus says to Tityrus in lines 46-47: M. Fortunate senex, ergo tua rura manebunt/et tibi magna satis, quamuis lapis omnia nudus (Meliboeus: Happy old man, so these fields will remain yours, and large enough for you, although everywhere there are exposed stones). In lines 67-72, Meliboeus bewails the misfortune of never seeing his homestead again and having to leave his native place. The poet's sympathy is for the loser, Meliboeus, who in Ecl.1.67-72 says:

\section{M. en umquam patrios longo post tempore finis pauperis et tuguri congestum caespite culmen, post aliquot, mea regna, uidens mirabor aristas? impius haec tam culta noualia miles habebit, barbarus has segetes: en quo discordia ciuis produxit miseros: his nos conseuimus agros!}

(Meliboeus: Tell me, shall I ever, in future, see again with amazement the land of my family and my humble cottage's roof covered with turf; shall I, after I don't know how many years, see with amazement my ears of corn, my kingdom? For a godless soldier will own this well-tended fallow land, a bloody soldier these crops! See where civil war has brought us, wretched citizens! For these people we have planted our fields!)

In the first Eclogue, Vergil praises Octavian for bringing hope of peace and stability, but the six lines near the end of the poem suggest that it is also a sad poem marked by embitterment and despair caused by the expulsion of the small farmers. The word barbarus in line 71 does not refer to a foreigner, but to a brutal Italian soldier who has received Meliboeus' land in the resettlement programme. These last lines make it a poem with political content, and show criticism of Octavian, who was personally involved in the resettlement programme ${ }^{75}$.

Scholars generally accept that Ecl.2 (together with 3) belongs to Vergil's earliest work $^{76}$. The second Eclogue is a love poem in Hellenistic fashion against a Vergilian background showing the contrast between the simple and good life in the country and the imminent corruption of the city. The poem tells us that the shepherd Corydon, modelled on Polyphemus of Theocritus' eleventh Idyll, is hopelessly in love with the boy Alexis, who is kept by their master in town. Apart from the Vergilian theme of

poetry as well is dependent on forces beyond it." Nauta however also makes the functional point: "And indeed the praise for Octavian is inextricably linked with the criticism: if there were no dispossessions, there would be no need for the saving grace of an intervention by a beneficient ruler." I interpret the criticism as the dominant mood of the poet. (emphasis is mine).

75 Cf. Dominik (2009, 122): "Octavian, who presided over the land evictions of 41 BCE in the aftermath of the triumviral settlement imposed on Italy after the battle of Philippi."

76 The book of Eclogues was presumably written between 42 B.C. and 35 B.C. The year 42 is derived from the assumption that Ecl.2 and 3 were probably the earliest and were written before Ecl.9, which was written in 41 or 40 B.C. The year 35 B.C. results from the reference to Octavian in Ecl.8.6-13. See also: Clausen (2003, xxii-xxiii); Perutelli (1995, 28-31). 
the pure country and the evil town, the poem also expresses the power of the absentee landlord over the life of the farmer.

The third Eclogue is influenced by Theocritus' fifth Idyll. Ecl.3 has two parts: the first contains the conversation between two herdsmen preparing for their singing contest and the second concerns the contest proper. In the third Eclogue the theme of the threat to pastoral life which we saw in the second Eclogue is maintained and expanded. The opening portrays the lack of care of the herdsmen, Menalcas and Damoetas, for their sheep and the suffering of the flocks. It presents the dark side of their work when they destroy the vines (line 11) atque mala uitis incidere falce nouellas (and wrongfully cutting through newly planted vines with an evil pruning-hook), or try to steal goats (lines 17-18) non ego te uidi Damonis, pessime, caprum/excipere insidiis (Didn't I see you, mischief, ambushing Damon's goat).

In the second part of the poem, the two herdsmen decide to turn to poetry and commence a singing match. They settle on the prizes. Menalcas' prize is a pair of beautiful beech cups and Damoetas also brings a pair of goblets along; according to Putnam "these are strange objects for a humble shepherd to be carrying around esoteric and highly cultivated" (Putnam, 1970, 125). Thus, these simple country folk possess unexpected qualities of appreciation of the beauty of the arts, and this is one of the ways in which Vergil glorifies the simple country life. Towards the end of the poem Asinius Pollio, lover of pastoral poetry and poet of tragedy himself, appears. At the time of writing this Eclogue Vergil and Pollio were friends. By introducing him, Vergil makes the point that in fine poetry simple rural people can engage with the sophistication of the elite. In fact, unsophisticated people can attain Pollio's poetic grandeur and reap the fruits of honey-sweet success; lines 88-89 say: D.Qui te, Pollio, amat, ueniat quo te quoque gaudet;/mella fluant illi, ferat et rubus asper amomum (Damoetas: he who loves you, Pollio, may he come where he is glad that you are also there; honey may flow for him and the bramble may bear fragrant fruit). The poem ends in a positive vein. Poetry has a stimulating effect on the two men: Vergil shows in lines 92-103 how, after they had lost themselves in poetry, they appear to change into caring herdsmen. Their singing match ends in a draw. When Vergil wrote this poem, probably in late 42 or early 41 B.C., he had just witnessed or was still close to the traumatic experiences caused by the expropriation of the land and farm of many people in his immediate environment. He expresses the wish to be a poet of pastoral song and to reach the same heights as his friend Pollio. But in Ecl.3 Vergil also shows his resolve to depict the farmers' life, reflecting on the noble values of life in the countryside which were under siege.

The fourth Eclogue was probably written in 40 B.C., or at least no later than 37 B.C., when Mark Antony broke with Octavia. Ecl.4 is the famous poem in which Vergil writes about the birth of a saviour, and about his vision that the Golden Age was to be restored to man. In lines 4-5 he refers to the prophecy of the Sybil of Cumae: Vltima Cumaei uenit iam carminis aetas;/magnus ab integro saeclorum nascitur ordo (The last age of Cumaean song has now come; the great line of centuries is born afresh). 
Harrison (2007c, 38) refers to the possibility that some Sibylline oracles "may possibly treat Roman political issues of the period of Eclogue 4 (41-40 BC), even an Egyptian queen who may be Cleopatra." However, he (note 12) also mentions "recent scepticism on the identification." Indeed, the pact of Brundisium between Antony and Octavian had brought hope of a lasting peace (Cf. Clausen, 2003, 120-121). The restoration would begin at the time of Asinius Pollio's consulship in 40 B.C. and coincide with the birth of a child (lines 8-10), the hoped-for son of Octavia and Antony: the latter can be deduced from lines 15-17, which refer to Hercules, whom Antony claimed to be his ancestor. Although Ecl.4.17 pacatumque reget patriis uirtutibus orbem (and he shall rule the world pacified by his father's bravery) could be interpreted as referring to just Antony, it is more likely that Vergil refers to Antony and his hoped-for son. Similarly, it should be noted that the reference to Hercules in the last two lines of Ecl.4 is a functional model, confirming the identity of the expected child, who, as Antony's son, descended from Hercules ${ }^{77}$. These final lines (Ecl.4.62-63) are: incipe, parue puer: qui non risere parenti,/nec deus hunc mensa, dea nec dignata cubili est (Begin, little boy: at whom his parents did not smile, and whom no god deemed worthy of his table, and no goddess of her bed). Vergil thus expected that Antony - and not Octavian - would bring peace to Italia. This is not surprising as Antony was in reality the prominent leader in the years immediately after Iulius Caesar's death. Vergil belonged to Antony's party and was a friend of Pollio, at that time one of Antony's most trusted lieutenants. Vergil also testified that he expected that the son would assume power (reget orbem) after his father, thus accepting some form of hereditary succession in a quasi-royal line, that of Antony. However, Antony's and Octavia's wedlock produced a daughter and was dissolved soon after, when Antony returned to Cleopatra.

Ecl.4 is a poem of hope for peace and the return of order to the farming lands of Italia and, as the child grows up, the expansion of Roman power, particularly in the East: iterum ad Troiam magnus mittetur Achilles (great Achilles will be sent again to

77 Cf. Clausen (2003, 121-125, and 144-145). Ecl.4.15-17 and Ecl.4.62-63 refer to Hercules; the last line specifically to Odysseia.11.602-604. Antony should be considered the father of the child. Nisbet (1978, 70) states: "the mother is presumably Octavia." See also Nauta $(2006,329)$. Three other views are relevant. Gordon Williams $(1974,45)$, states that the child could have been born either from the marriage of Antony and Octavia or from that of Octavian and Scribonia, who had married a few weeks before Brundisium. He prefers the second option. Veyne $(1997,25)$ asserts that the annunciation had nothing to do with reality and that "the Child does not exist, or rather it is every child at once." I do not concur with either Williams' or Veyne's view on the child's descent. Both scholars overlook the significance of the clear reference to Hercules in the last two lines of the poem. The third view is that of Harrison (2007c, 40-42), who leaves the question whether Antony or Octavian was "the more likely sire of a great dynasty" open "for it would be a brave poet who would have made a firm choice in 40 B.C.." I argue that Vergil made this choice as it reflected the political situation in 40 B.C. Thus, Clausen and Goold's $(1992,110)$ suggestion that the poem is about a child of Antony and Octavia is very credible. See also also Wilkinson (1997, 35-39). In the words of Clausen (2003, 125): "Failure of historical perspective vitiates much that has been written about the Fourth Eclogue.” (my emphasis). 
Troy) (line 36). The blessings of the "Golden Age" were to spread over the whole earth and the land would bring forth the produce without hard labour. However, things worked out differently. The Pact of Brundisium did not hold, Octavian had to continue fighting the civil war and eventually had to confront Mark Antony; in the end the power struggle was decided in the sea battle near Actium ${ }^{78}$. The lines 53-54 suggest that Vergil intended to eulogise the newly born prince. In Ecl.4 Vergil gave a powerful political statement about his preference for a hereditary form of non-elected political authority and one-man rule. Nauta $(2006,327)$ interprets Ecl.4 as "praise of an unborn boy.” Indeed, Vergil expresses his expectations for Antony's unborn child, who turns out to be a girl. If the poem is classified as panegyric, I would label it as praise of a political view, the kingship. At the time of writing, Vergil did not know that he was later to transfer his allegiance to Octavian.

In the fifth Eclogue, Vergil demonstrates again his leaning towards pastoral poetry. However, this poem also contains references to contemporary themes, which lie deeply hidden in the text, for example Vergil's love for the countryside, the simple and honest life of the shepherd and the suffering of the land and the farmer.

Ecl.5 is about two men, the young newcomer Mopsus, and the older shepherd Menalcas, who decide to make music and to sing. The name of Mopsus returns in $E c l .8$ and in both poems the name is Vergil's functional model to indicate a stranger ${ }^{79}$. "Mopsus" alludes to the men who, following the recent expropriations, had moved to areas where previously only small farmers and herdsmen worked and lived. In this Eclogue one finds several indications of this. The first is in the opening lines of the poem: Me. CVR non, Mopse, boni quoniam conuenimus ambo,/[...] consedimus [...]? (Menalcas: Mopsus, why do the two of us not sit down, [...] since we have come together, both good at ...?). The formality of the opening may be the result of Menalcas' apprehension about the intentions of the recently arrived Mopsus and their short acquaintance. There is a second indication in the manner in which Menalcas

78 Nauta (2006, 330-332) points out an interesting intertextuality between on the one hand Ecl.4 and on the other the beginnings of the sixth and seventh books of the Aeneid (A.6.86-94 and A.7.41-45). He (2006, 332) sees a clash between the two. Ecl.4 concerns the "wars that would lead to the restoration of the Golden Age." The two passages in the Aeneid concern "the wars that Aeneas will wage in Italy." 79 Clausen $(2003,155)$. Vergil's inspiration from Theocritus can be seen in his choice of the shepherd's names in the Eclogues. Many of these (12 of 19), such as Amyntas, Corydon, Daphnis, Menalcas, Tityrus, and others, come from Theocritus' Idylls. But not Mopsus. Mopsus (Mółoৎ) was a mythological hunter and warrior mentioned by Apollonius Rhodos. He was a member of the crew of the Argo and also a seer who counselled Iason. Ovid (Met.8.350) mentions Mopsus who joined Meleager as a hunter. See also: Perutelli (1995, 42-44). Clausen (2003, 155) says of Mopsus' name: “Mopse, not a pastoral name before Vergilius; perhaps borrowed from Ap. Rhod. 3.916-18." See also the discussion on Ecl.8 below. It is of course possible that Theocritus used the name of Mopsus in work that has been lost to us, but was still extant in Vergil's time and not part of Artemidorus' anthology. However, when Mopsus features in other work than Vergil's he is not a shepherd but a fighter or at least a member of a group of fighters. 
grovels before young Mopsus, and pays him compliments, by comparing him to the best singer in the region, Amyntas. During the wrangling as to who will sing first and where, one reads in lines 8-9: Me. Montibus in nostris solus tibi certat Amyntas./Mo. Quid, si idem certet Phoebum superare canendo? (Menalcas: In our hills only Amyntas vies with you. Mopsus: What then, likewise if he competes with Apollo to excel him in singing?).

Mopsus is different and appears to feel rather superior to Menalcas. In the words of Clausen (2003, 151): "Menalcas tactfully changes the subject and invites Mopsus to begin." The younger one starts with a song about Daphnis' death. One can read a reference to the state of the countryside in Mopsus' song. Putnam (1970, 172-173) makes this point discussing lines 20-44, especially the opening lines: Mo.Exstinctum Nymphae crudeli funere Daphnin/flebant [...],/cum complexa sui corpus miserabile nati/atque deos atque astra uocat crudelia mater (Mopsus: The Nymphs lamented over Daphnis, cut off by a cruel death, [...], when his mother holding tight her son's piteous body calls upon both gods and stars for their cruelty). According to Putnam (1970, 172): "To sing of death in a sylvan setting is ominous enough; the elegiac tone is not consonant with the pastoral world's assumed idealism. But to mourn for the 'cruel' demise of Daphnis, bucolic hero par excellence, is to hint at the ruin of the landscape." Later in the same passage (lines 34-39) Mopsus complains again of the destruction of the pastoral paradise. Lines 38-39: Mo.pro molli viola, pro purpureo narcisso/carduus et spinis surgit paliurus acutis (Mopsus: Instead of the soft violet, instead of the brilliant narcissus, the thistle springs up and the thorn with its sharp prickles).

It is time for Menalcas' reply. Daphnis has been deified and in Ecl.5.56-61 Menalcas sings that Daphnis looks down from the Olympus and sees Mopsus' dead landscape come alive again. Menalcas twice exalts Daphnis to the stars (lines 5152) and thus to immortality: Daphninque tuum tollemus ad astra;/Daphnin ad astra feremus (and we will lift up your Daphnis to the stars. Daphnis we will lift up to the stars). Mopsus, however, only sings of Daphnis' fame reaching the stars (line 43), emphasizing instead his death: Daphnis ego in siluis, hinc usque ad sidera notus (I was Daphnis amid the woods, from here to the stars known) ${ }^{80}$. Vergil displays the different attitudes of Menalcas and Mopsus: on the one hand Menalcas, the native rural man, who expresses his hope that his beloved country will be restored, and on the other Mopsus, the arrogant young newcomer, who cannot see further than his immediate gain and who grumbles about the poor condition of his land. The poet points out that Daphnis, "bucolic hero par excellence" (see above), is now far away among the gods, and that the indigenous farming population cannot rely on him to restore normality. Daphnis looks down from heaven and sees the ruined land achieve peace as if the

80 Lowrie (2009, 145-150) stresses the performative aspects of poetry and Vergil's view on its power. She interprets political issues, such as the land appropriations, as only contingent. 
Golden Age had returned. Lines 60-61 say: nec lupus insidias pecori, nec retia ceruis/ ulla dolum meditantur: amat bonus otia Daphnis (Neither does the wolf design an ambush against the flock nor nets a trap against the deer: kind Daphnis loves peaceful calm). However, this was not to materialize immediately. Vergil, observing the ravages of a political strife which was still raging when he wrote this poem (about 40 B.C.), describes a future with peace and stability as still distant. When it finally arrives, farmers will be able to work their fields again and offer their prayers to Bacchus and Ceres as of old (lines 78-80).

The sixth Eclogue starts as a recusatio, as Vergil declines to write about the military successes of Alfenus Varus, a most undistinguished soldier. Vergil pays him a compliment (lines 11-12), however, as he knows that he needs the goodwill of the land commission, or perhaps of Varus himself, as he may have been in charge of land confiscations in the region at a time when many of the Mantuan people stood the possibility of losing their property. Vergil affirms that, instead of writing a panegyric poem for Alfenus Varus, he will write pastoral poems. In Ecl.6.6-8 he notes that there are enough poets willing to sing Varus' praises, but that he agrestem tenui meditabor harundine Musam (now I will exercise myself in the rustic Muse on a fine reed). Although the poem is addressed to Varus, the central figures are Silenus and C. Cornelius Gallus; the latter is introduced in line 64. In his commentary on Ecl.6.64 (Thilo, 1887, 77), Servius states that Gallus was in charge of taxing the townships in Northern Italia (qui [Gallus] a triumviris praepositus fuit ad exigendas pecunias ab his municipiis). In his Commentarii Vergiliani.13 (on Ecl.9), Donatus says also that Gallus was involved in the land distributions in Gallia Cis-alpina in 42-40 B.C.: sed postea et per Maecenatem et per triumviros agris dividendis Varum, Pollionem et Cornelium Gallum [...] agros recepit (but later he [Vergil] got his land back through [the agency of] Maecenas, and the three joint commissioners for the land division Varus, Pollio and Cornelius Gallus). As stated in the introductory section above (3.1.1), it is doubtful that Varus and Gallus were in fact involved in the expropriations in the Mantua region. In the same section, I also explained that it is feasible that Vergil used their names to symbolise the actual involvement of high-ranking officials: I will interpret the references to Varus and Gallus in the present poem along these lines. Gallus' role will be examined more extensively in our discussion of Ecl.9 and Ecl.10 ${ }^{81}$.

Two young shepherds find Silenus, drunk as usual, asleep in a cave and awaken him, aided by the beautiful Naiad Aegle. They make him sing. In lines 31-42, Silenus first sings a cosmogony, about the creation of order, - et rerum paulatim sumere formas (and gradually to take up the forms of things) (line 36) -, the repopulation of the earth after the flood (Pyrrha, line 41), and Prometheus' gift of fire to mankind (line

81 For Alfenus Varus' and Gallus' involvement, see Bowersock (1971, 75-76); Clausen $(2003,181)$ and my notes 69 and 91. The text of Donatus is at: www.intratext.com. See also Patterson (1987, 31-34); Ruikes (1966, 67, note 43); Wilkinson (1966, 320-324). See for Gallus: Gibson, 2012. 
42). This is followed by a passage (lines 43- 73) in which Silenus sings four short references to mythological figures, comprising one or two lines, and two stories: that of the mythological Pasiphaë (lines 46-60), and that of the living poet Gallus (lines 64-73). Vergil cuts Silenus short - quid loquar aut [...] ut narrauerit? (why tell that he sang either of [...]?) - and he finishes Silenus' song in lines 74-81 with the stories of Scylla and Philomela. Many different interpretations of Silenus' song have been given, generally from the perspective of literary history and literary model ${ }^{82}$.

Before interpreting Ecl.6, the structure of Silenus' song needs considering. After Silenus has opened with the cosmogony, the second part of his song presents three themes within a specific structure. This contains an opening with a short reference to Hylas, followed by the more extensive passage about Pasiphaë (15 lines). Next, there are again two short references, to Atalanta and to Phaëthon's sisters, after which follows the passage about Gallus (10 lines). Finally, the song finishes with two short references, to Scylla and to Philomela. Each pair of characters represents a theme: (1) Hylas' and Pasiphaë's theme is uncontrolled passion, (2) references to Atalanta and Phaëton are about fateful ambition and recklessness, and (3) Scylla and Philomena refer to murder, either of passing Homeric sailors or their next of kin. Towards the end of the song, Vergil's friend Gallus appears abruptly amidst this gathering of mythological figures to meet Linus, "a shepherd of divine song” (diuino carmine pastor), on Mount Helicon. In lines 69-70, Linus gives Gallus Hesiod's reed pipes: dixerit: 'hos tibi dant calamos (en accipe) Musae,/Ascraeo quos ante seni (he said: "these pipes give you the Muses (see take them), which once they gave to old [Hesiod] of Ascra) $)^{83}$.

Two aspects of the poem are significant for an interpretation from a functional point of view: firstly, the meaning of Silenus' song, particularly the passages about the cosmogony and Pasiphaë; secondly, the roles of Alfenus Varus, Silenus and Gallus. In Silenus' song, Vergil refers to the actual political and social state of affairs in the countryside near Mantua. The song evolves from picturing a situation of order and concord in the cosmogony, to several cases of disorder, confusion and discord, such as uncontrolled passion, fateful ambition and murder, all of which Vergil encountered in his own time. The myth of Pasiphaë's impossible and unhappy love for a bull alludes to this. The bull lives in a perfect, pastoral environment enjoying himself with a heifer (lines 53-54). The woman lacks these happy blessings when she roams through the countryside (line 52): a! uirgo infelix, tu nunc in montibus erras (Ah! unhappy girl, you

82 Clausen (2003, 175-178); Coleman (1981, 203-206); Harrison (2007c, 48-56). See also note 11 in section 1.2.3.

83 Clausen (2003, 203): "giving the pipes of a dead singer to a worthy successor was a pastoral tradition." Nauta (2006, 320-321) states: "Although Gallus receives calamos [pipes] (1.69) from Linus.... pastor (1.67), it is not bucolic poetry that he is going to write, nor is it panegyric:" Gallus is going to write aetiological poetry. This is important with regard to the interpretation of the opening lines of Ecl.10 below. 
now stray about the hills). Vergil is referring to the Fall of man in mythological times: Pasiphaë, possessed by madness, has lost control (line 47, dementia cepit), while the bull is calm. Her passion for the animal is so extreme that she wants him back and she calls upon the Nymphs to help her return the bull home (lines 55-60). It is a world upside down: the beast is lord and man has lost control. Coleman $(1981,192)$ observes that "the tracks of the bull, for whom errare is part of normal life, mock the woman who is now alienated from her own way of life," and he $(1981,205)$ states: "there is therefore an implicit contrast between Amor as a principle of creative concord in the natural world [cosmogony] and Amor as a discordant and destructive force in human affairs - Pasiphae, Scylla etc.” Thus, this mythological reference may allude to the ravages caused by the destruction of nature through human aberrations, such as Vergil experienced in his own part of Italia.

As I explained above Varus, Silenus and Gallus also symbolise this unhappy state of affairs. In expressing the ruin of traditional country-life, Silenus, the boisterous man blessed with down-to-earth wisdom, voices the views of the common farmer. Vergil's contemporaries Varus and Gallus typify the involvement of high-ranking Romans in the expropriations near Mantua, with an unreasonably harsh Varus in charge and Gallus attempting to mediate. This is most likely also the reason behind the different treatment of the two men in the poem. Varus is refused a panegyric, whereas Gallus is generously praised in lines 64-66: Gallum/[...],/utque uiro Phoebi chorus adsurrexerit omnis (Gallus, how the whole choir of Phoebus rose to the soldier and man of honour). Gallus is called uir, which in this context means more than simply "man". The adjacency of uiro and Phoebi has a special significance, accentuating Vergil's respect for him (Cf. Clausen, 2003, 202). In Silenus' song, Gallus typifies Vergil's hope of saving the countryside, since he is not only Vergil's friend and fellow poet, but also a general and politician and an associate of Octavian (see also Putnam, 1970, 212-215).

This interpretation of $E c l .6$ differs substantially from that of several scholars, who are mainly concerned with Vergil's poetic orientation and/or his literary models. A few examples: Williams $(1968,249)$ interprets Ecl.6 "as a poem addressed to Varus and enclosed within two references to the inspiration of Apollo.” He (1968, 249) also states: "the other relevance which the [Gallus'] passage has in the song of Silenus is that it introduces Apollo, who lies behind both Virgil's poem and the song of Silenus, as the inspirer of yet another poet [Gallus]." Coleman $(1981,206)$ refers to "Theocritus' literary manifesto in Id. 7." Martindale $(2000,111)$ noting the intertextuality of Ecl.6 in general and of Silenus' song in particular - both with respect to Vergil's predecessors and to Ovid in the Metamorphoses - remarks that "Eclogue 6 is now normally read metapoetically, as a poem about poem-making." He $(2000,112)$ sees the passage about Pasiphaë as "poetics of eros." Clausen $(2003,177)$ does not recognise the above interpretation of Vergil's reference to Pasiphaë, stating "that Pasiphaë's perverse passion [...] (45-60), and the literary initiation of Gallus (64-73) occupy so much of the song is indicative of contemporary taste, Virgil's and that of his friends." More specifically about the Gallus' passage, Clausen $(2003,200)$ states: 
“the only interpretation which V[ergil]'s lines (64-73) will bear is the obvious one: [...] he [Gallus] rises, so to speak, from a lower to a higher level of poetry (Hippocrene), from love-elegy and Lycoris to aetiology and the Grynean Grove [a cult-place of Apollo].” Nauta (2006, 320-321) interprets the Gallus' passage in the same way, and sees the lines on Gallus as "praise, but praise of his poetry, and that this poetry is characterised as different from, but related to Virgil's.” Gibson $(2012,179)$ - in his paper on Gallus - sees Ecl.6.64-73 as "telling us that Gallus - in a generic ascent up the mountain of poetry - must now begin writing verse in the aetiological tradition." Similarly, Raymond $(2013,65)$ also reads "Gallus leaving the valley of Permessus for the mountains of Helicon” as Gallus' "literary movement from love elegy to the higher level of Callimachean aetiology." None of the modern scholars concludes from the Gallus' passage that he changed to writing pastoral poetry ${ }^{84}$.

The above interpretations all belong to the literary frame. Although part of the poem is rightly identified as Vergil's search for his poetic allegiance and literary model, Vergil also pursued a second objective. The functional references to the derangement of Pasiphaë, to other mythological figures and to Alfenus Varus, Gallus and the land confiscations may be seen as a commentary on contemporary events, expressing Vergil's anxiety about the radical changes in Italia and the destruction of the traditional social and economic relationships of the rural population, for which men close to Octavian shared the responsibility, as well as his hope that the situation may improve.

In the seventh Eclogue Meliboeus encounters two herdsmen, Corydon and Thyrsis, and Daphnis, the ideal pastoral poet. Although Corydon and Thyrsis are Arcades ambo (Arcadians both) (line 4), Vergil situates the meeting on the bank of the river Mincius (modern Mincio), near Mantua ${ }^{85}$. The two herdsmen are "equal in singing, ready to respond" (line 5), while Daphnis sets the standards. The serious singing begins in line 29 as the shy and gentle Corydon and the smug budding poet Thyrsis offer their praises, one to Diana and the other to Priapus, and both to Galathea, to other gods such as Bacchus and Venus, and finally to love and nature.

The poem is set against the background of pastoral life, making a sharp contrast between Corydon's positive, loving and generous attitude to nature and Thyrsis' pessimistic, crude, and arrogant attitude. For instance, lines 33-34 refer to Thyrsis'

84 Ross, Jr. (2008/1975, 189-215 = Ross 1975, 18-38) gives the Gallus' passage a very different interpretation within the literary frame. Quoting Volk's $(2008,14)$ summary, he writes: "a scene that he [Ross] suggests is based on an episode in Gallus' own writing. Ross shows how Vergil, following Gallus, constructs a 'poetic genealogy' that leads from Apollo, via Orpheus and Linus, Hesiod, and Callimachus and other Alexandrian authors, and how the poet places himself in that same tradition." I will not discuss Ross' view in this book, as it is too far removed from my focus.

85 Jenkyns (1989, 32) argues rightly that Arcades ambo signifies that the setting cannot be Arcadia; “if some character in a book says 'I have just met two Englismen,' we can be virtually certain that the scene is not laid in England. I would not say this in Surrey; I might well say it in Paris.” 
lack of interest: T. Sinum lactis et haec te liba, Priape, quotannis/exspectare sat est: custos es pauperis horti (Thyrsis: A bowl of milk and these cakes, Priapus, once a year, are more than you can expect; you are guarding a poor garden). In lines 46-47, we encounter the contrasting positive picture of Corydon, who praises the arbute tree for providing shade for his flock: et quae uos rara uiridis tegit arbutus umbra,/solstitium pecori defendite (and the green arbute that shelters you with thin shade, keep the summer heat away from my flock ${ }^{86}$. Vergil shows us these contrasting attitudes in order to denounce the changes that were taking place in farming in Italia, which he considered as negative and reprehensible. The poet refers to these changes by deliberately setting the poem in his native region (river Muncius) where large-scale land appropriations were taking place. Like in Eclogues 5 and 8, the poet's choice of the name of one of the herdsmen, Thyrsis, who is portrayed as an outsider and as hostile to farmers' life, is significant. Many of the names of Vergil's herdsmen come from Theocritus' Idylls (see note 79). The name of Thyrsis is most likely derived from $I d .1^{87}$. Although in this Idyll, Theocritus' Thyrsis is a herdsman and experienced "master poet" (Id.1.20), his namesake in Ecl.7 is the loser in the singing match. In the last line of Ecl.7 Vergil confirms the superiority of the poet and traditional herdsman Corydon over Thyrsis, the outsider: ex illo Corydon Corydon est tempore nobis (from that moment Corydon is the Corydon for us). In the words of Clausen (2003, 232): "the name becomes metaphorical: not simply Corydon, therefore, but Corydon the ideal singer." The supposition that Vergil portrays Thyrsis as an outsider fits in with the following: many names occur in more than one Eclogue, but Thyrsis appears only in this poem. The book of Eclogues contains only three more places where Vergil uses a particular name only once. In those instances he always portrays someone who is relatively alien to the traditional pastoral setting ${ }^{88}$.

Thus, although the seventh Eclogue is wrapped in the form of a conventional pastoral poem, it also refers, on the one hand, to the genuine farmers and herdsmen of old with their love for their flocks and the countryside (Corydon), and on the other hand to uninterested outsiders and nouveaux riches, the new landowners (Thyrsis). Many of these had made their fortunes during and after the civil war and through land confiscations. Vergil had experienced most of the smallholders being reduced to beggary and had seen his old beloved Italian countryside disappear. It is likely that the poem was written after 40 B.C.. The poem is a critical statement by Vergil about social and political developments in his time.

86 Coleman (1981, 226); Coleman (ad. loc.) classifies exspectare sat est as "impudent." See also Clausen (2003, 211).

87 For Id.1 see Gow (1986, vol.II, 1-32) and Hunter (1999, 60-107, esp. at 61).

88 Palaemon in Ecl.3.50 and 3.53, refers (acc. to Clausen, 2003, 104) to a "most immoral grammaticus." Stimichon in Ecl.5.55 cannot be traced (acc. to Clausen, 2003, 167), and Antigenes in Ecl.5.89 has a minor role (Clausen, 2003, 108). 
Immediately after the opening lines of the eighth Eclogue, Vergil mentions an unnamed patron about whom Clausen $(2003,233)$ remarks: "were they [lines 6-13, in which the patron is mentioned] to be removed, their absence would not be felt." Although Clausen sees the lines as superfluous, he (2003, 233-237) analyses the question thoroughly and concludes that the patron is Octavian and not Pollio. His first argument is taken from history and geography: in lines 6-7 Vergil says about the patron: seu magni superas iam saxa Timaui,/siue oram Illyrici legis aequoris (whether you are already sailing past the rocks of the great Timavus, or passing the coast of the Illyrian sea). The Timavus, a river in North Italia, flows into the Gulf of Trieste near Aquileia. It is unlikely that these lines refer to Pollio's return to Italia after his campaign against the Parthini in 39 B.C.. A return via the Aquileia region would have entailed a rather dangerous, circuitous sea journey. Octavian, however, campaigned not far from the Timavus region in 35 B.C.. According to Clausen a second argument lies in the reference to Sophokles in lines 9-10: en erit ut liceat totum mihi ferre per orbem/sola Sophocleo tua carmina digna coturno? (Say, shall I ever be permitted to bring throughout the world your songs, which alone are deserving of the buskin of Sophokles?). It is thought that this may refer to Octavian who had begun composing his tragedy Ajax. Pollio's renown as a tragic poet was too great to receive such an expression of hope for his future. A third argument (Clausen, 2003, 237) is found in a quotation from QUINT.Inst.10.1.91-92, where in congratulating Domitian "on his accession to the throne, and extolling his [Domitian's] literary genius, he [Quintilian] quotes the last line of Virgil's dedication": line 13 of the eighth Eclogue. Clausen makes the point that Vergil's dedication must have been to Octavian, as Quintilian would not have used a dedication to the rather unknown Pollio. Finally, Clausen argues that the words of lines 11-12 - accipe iussis/carmina coepta tuis (accept the songs begun at your command) - refer to a possible patronage of Vergil. Clausen $(2003,236)$ asserts that "if Pollio ever was Virgil's patron, he has been superseded, since the First Eclogue effectively dedicates the Book of Eclogues to Octavian.” In my view, Clausen presents persuasive arguments - particularly his first and third - that Octavian is the most likely dedicatee and consequently that $E c l .8$ was written in or after 35 B.C. ${ }^{89}$.

Apart from the opening, the poem consists of two parts, in which two herdsmen, Damon and Alphesiboeus, each sing a long song. The first song, Damon's, is about a shepherd who has lost his girl (Nysa). He had hoped to marry her, but she was given away to another man (Mopsus): Mopso Nysa datur (Nysa is given to Mopsus) who is told: Mopse, nouas incide faces: tibi ducitur uxor (Mopsus, cut new torches: your

89 For the suggestion that Octavian is the dedicatee see also Bowersock (1971, 73-80); Nauta (2006, 310-316); Rudd (1976, 122, note 10). Different views are given by Coleiro (1979, 259-261); Perutelli (1995, 29-31); Putnam (1970, 255); Tarrant (2000, 174 note 14). Lowrie's interpretation of the addressee of the poem (Lowrie, 2009, 144-5, esp. at 144) differs considerably. Similarly to Ecl.5, she focuses on the performative aspects of Vergil's poetry and his search for the right genre. 
bride is brought) (lines 26 and 29). Putnam (1970, 261-278) does not specify whether Damon's shepherd's lament is a result of having lost his girl to another shepherd. But suppose that Mopsus is not a shepherd. There are some indications for this in lines 32-33. Nysa is digno coniuncta uiro (wedded to a real gentleman) and she is described as dumque tibi est odio mea fistula dumque capellae (while you hate my pipe and my goats). One would hardly expect her to marry another shepherd if she hates his work so much. Could Mopsus, instead of a shepherd, be a newcomer, perhaps a soldier who has been given a piece of land (see note 79)? The social order has been upset and the shepherd's life has been irrevocably changed. Even nature is confused, when griffins mate with mares: iungentur iam grypes equis, aeuoque sequenti cum canibus timidi uenient ad pocula dammae (soon griffins shall mate with horses, and in the next age timid deer will come together with dogs to the drinking places) (lines 27-28). Strangers dictate life and what the shepherd has known and loved since childhood is lost. If Damon's song is read in this way the question of the dedication to either Octavian or Pollio is particularly meaningful. Vergil wants the addressee to be aware of the grave situation in the countryside and the destruction of traditional life. Octavian, the man who is responsible, ought to do something about it.

Vergil also refers to the destruction of life in the countryside in Alphesiboeus' song. This song concerns a woman who has lost her coniunx; he has left her and the countryside for the city. Ecl.8.64-68 depicts her predicament:

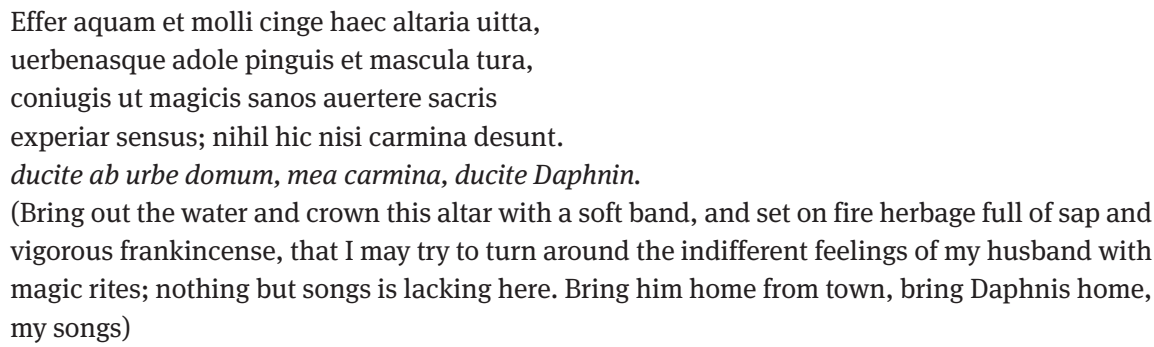

The theme of these lines resembles that of Damon's song. Just as he sings about a shepherd who has lost his girl Nysa to a man who did not belong to the shepherd's world, Alphesiboeus sings about a woman who likewise lost her man Daphnis to a girl who did not belong to her world. However, the sorrows are resolved in different ways. Damon finishes his song with praeceps aërii specula de montis in undas/deferar (head first I shall cast myself down from the high mountain top into the waves) (line 59-60). Alphesiboeus' woman, instead, places her trust in the power of magic and song, as lines 69-70 testify: carmina uel caelo possunt deducere lunam,/carminibus Circe socios mutauit Vlixi (Songs can even bring down the moon from heaven, and by songs Circe has changed Odysseus' comrades).

$E c l .8$ is a poem about the destruction of the normal life of the countryside. There are two reactions: Damon's shepherd is driven to suicide, but Alphesiboeus' woman 
uses poetry as a healing power. The woman is the stronger personage, but both suffer from the disruptions of their lives. Both the shepherd and the woman represent the positive values of pastoral life, such as home, fidelity and genuine love, while Nysa and Daphnis represent opposite values.

At the end of the poem, when Alphesiboeus finishes his song in line 109, all seems to turn out well for the woman, as she says in a variation on the refrain: parcite, ab urbe uenit, iam parcite carmina, Daphnis (Stop! Daphnis comes home from town, stop now songs). Vergil testifies that the values of pastoral life, as expressed through her song, eventually triumph. This is his message of hope. Putnam's $(1970,291)$ closing remarks about the eighth Eclogue refer also to this optimism: "The first song is essentially a tragic vision, looking at the end of a pastoral dream. The second offers a renewal of happiness after a time of uncertainty." But is there really a happy ending? The penultimate line (108) is credimus? an, qui amant, ipsi sibi somnia fingunt (Can I believe it? Or do lovers make up their own dreams?). The woman expresses her disbelief that all is well; her feeling is that everything is still in chaos. Therefore, contrary to Putnam's $(1970,290)$ view, that "like Eclogues 6 and 7 it [Ecl.8] is a poem about the possibilities of bucolic verse, as form and as idea" and $(1970,292)$ that "the totality is once more a meditation on bucolic poetry, this time [in Ecl.8] specifically concerned with how love can either destroy or recreate the pastoral myth," the eighth Eclogue conveys primarily a different message: the uncertainty for the people of the countryside remains, as the civil war and its aftermath have destroyed the way of life in the countryside and with it the essential values of Italia. Vergil is critical of Octavian, to whom the poem was probably dedicated, and who, in his struggle for power, shares in the responsibility for the destruction of the traditional social structures of the country ${ }^{90}$.

There is a thematic connection between the ninth Eclogue and the first. Both poems are concerned with the evictions of the farmers and herdsmen from their land, which, after the battle of Philippi, was, in many parts of Italia, distributed among veterans. In the present poem, the poet describes the bitter situation now arisen. The poem's opening is very direct in describing the effects of the land confiscations. One can feel the anger and embitterment of the dispossessed in the first six lines. Moeris, who is now a tenant on his own old farm, brings his payment in kind to the new owner, an urban dweller: L. QVO te, Moeri, pedes? an, quo uia ducit, in urbem? (Lycidas: Where to, Moeris, afoot? Perhaps, where the road leads, into town?) (line 1). Moeris is particularly aggrieved that he is ordered off his old patch: M. [...], aduena nostri/ [...] ut possessor agelli/ diceret: ' haec mea sunt; ueteres migrate coloni' (Moeris: that a stranger, who now owns my little field, should say: "this is mine; move, tenant (of the past") (lines 2-4).

90 Contrary to Nauta (2006, 310-316). Although Nauta also considers Octavian the dedicatee, he does not mention the critical nature of the poem. I consider the criticism of Octavian the kernel of Ecl.8., making it less panegyric than Nauta suggests. 
Next, a poet, Menalcas, whom the others know (uestrum Menalcan) and who is personally involved, is introduced by Lycidas. This poet is said to have saved the area from dispossession (lines 7 and 10): L. Certe equidem audieram, [...] omnia carminibus uestrum seruasse Menalcan (Lycidas: Of course, what I have heard was that your Menalcas has saved all with his songs). Moeris, however, a true sceptic, says in lines 11-13 that one hears so many stories which are worth nothing. Songs are no match for the tela Martia (the weapons of war). In the central part of the poem, from line 17 onwards, the two men try several lines of Menalcas; for instance Ecl.9.26-29:

M. Immo haec, quae Varo necdum perfecta canebat:

'Vare, tuum nomen, superet modo Mantua nobis,

Mantua uae miserae nimium uicina Cremonae,

(Moeris: rather these, not yet finished, which he sang to Varus: "Varus, your name, let but Mantua remain for us, Mantua, alas, too much in the vicinity of unfortunate Cremona)

Who is Menalcas? Is he in Ecl.9.7-29 a reference to a living poet, perhaps Vergil himself? It is unclear whether this passage concerns Vergil. On the one hand the region described in lines 7-9 cannot be Mantua. Coleman $(1981,258)$ says about this: "Although ancient and modern commentators have seen in this [portrayed landscape] a description of Vergil's own ancestral farm, colles and fagos cannot be reconciled with the terrain of Mantua." On the other hand, several scholars suggest - based upon passages by Suetonius and Servius - that these lines refer to the putative efforts of C. Cornelius Gallus, who is supposed to have mediated between Vergil and Alfenus Varus, in an attempt to exempt the entire area of Mantua from confiscation. According to Servius and Suetonius, Varus was in charge of the land confiscations ${ }^{91}$. Servius' commentary on Ecl.9.7-10 (Thilo, 1887, 109-110) refers very specifically to the fact that the Mantuan area was involved (Wilkinson, 1997, 29): usque ad eum autem locum perticam limitarem Octavius Musa porrexerat, limitator ab Augusto datus, id est per quindecim milia passuum agri Mantuani, cum Cremonensis non sufficeret (to this spot Octavius Musa, the boundary commissioner [limitator] appointed by Augustus, had extended his border-poles, that is to say, through fifteen miles of Mantuan territory, since that of Cremona was not sufficient). The evidence for supposed involvement of Gallus, however, is very slight and should be considered as rather speculative. It is only based on two sources. Firstly, on Servius' commentary on Ecl.9.10 (Thilo, 1887, 110), where he quotes “a passage from

91 See also note 81. For Gallus and Varus, see: Wilkinson (1997 , 29-35, esp. 29-31); Wilkinson (1966, 320-324); and Hermes (1980, 212-257), who quotes the opinion of several scholars before 1977. For the confiscations in the Mantuan region and the speculation about the putative loss of Vergil's family farm (cf. Jenkyns, 1998, 170-171) see note 66. I offer no opinion whether Suetonius correctly records Vergil's motivation to start writing the Eclogues; for this see Clausen (2003, 174 note 1). Suetonius' text in Vita Vergili.19 is from Rostagni (1944, 84). 
a speech by ‘Cornelius' (presumably Gallus) against Varus” (Wilkinson, 1997, 31). There is no independent support for this identification. The passage (Thilo, 1887, 110) reads as follows: quod Mantuanis per iniquitatem Alfeni Vari, qui agros divisit, praeter palustria nihil relictum sit, sicut ex oratione Cornelii in Alfenum ostenditur cum iussus tria milia passus a muro in diversa relinquere, vix octingentos passus aquae, quae circumdata est, admetireris, reliquisti (because of the unreasonableness of Alfenus Varus, who divided the lands, nothing had been left for the Mantuans other than swamps, as appears from a speech by Cornelius to Alfenus stating: when you [Varus] had been ordered that you should measure out leaving three miles from the wall in every direction, you hardly left 800 paces of water which lie around it). The second source is Suetonius' (Vita Vergili.19) reference to Vergil being saved from loosing his land: Mox cum res Romanas incohasset, offensus materia ad Bucolica transiit, maxime ut Asinium Pollionem, Alfenum Varum et Cornelium Gallum celebraret, quia in distributione agrorum, qui post Philippensem victoriam veteranis triumvirorum iussu trans Padum dividebantur, indemnem se praestitissent. (Soon, when he [Vergil] began with a work about Roman history, but feeling that he made a mistake with [the choice of] the subject, he changed to the "Bucolics" particularly to praise in song Asinius Pollio, Alfenus Varus, and Cornelius Gallus, because - at the time of the distribution of the land, which beyond the Po was divided by order of the triumvirs among the veterans after the victory at Philippi - these men had saved him from the loss of his land). In this passage, it is not only Gallus who came to Vergil's rescue, but also Pollio and Varus.

Irrespective of the inconclusive evidence of Varus' and Gallus' involvement in the expropriations in the Mantuan area, Vergil testifies in the passage that efforts to exempt Mantua had been in vain, and that the town was affected by the expropriations because the force of arms, the tela Martia and the aquila, was stronger than poetry, nostra carmina. Vergil presumably did not refer to personal experience, but tapped into his personal knowledge to portray the general feeling among the population of the region. Vergil's frustration about the situation in the country can also be read in lines 35-36 when Lycidas, claiming to be a poet, says: L. nam neque adhuc Vario uideor nec dicere Cinna/digna, sed argutos inter strepere anser olores (as yet, it seems that I sing nothing worthy of Varius or Cinna, but that among tuneful swans I cackle as a goose). Both the dispelled farmers and the poets writing pastoral poetry are frustrated by the events, and feel that their poetry leads to nothing. However, Vergil's reference to cackling geese is presumably not only meant to slight the impact of Lycidas' poetry, but also as a subtle reference to geese giving warning signals.

It is likely that the present Eclogue was one of Vergil's first, written around 40 B.C.. Iulius Caesar had been murdered only four years earlier. In lines 46-50 Vergil makes a powerful political statement by alluding to Iulius Caesar. Lycidas sings five lines of what he still remembers hearing Moeris sing in the past: 
L. 'Daphni, quid antiquos signorum suspicis ortus?

ecce Dionaei processit Caesaris astrum,

astrum quo segetes gauderent frugibus et quo

duceret apricis in collibus uua colorem.

insere, Daphni, piros: carpent tua poma nepotes.'

(Lycidas: "Daphnis, why are you looking up at the new rising of old signs in heaven? See, the star of Caesar, of Dione's lineage, came past; the star which makes the fields rejoice with corn, and makes the grape draw in its colour on the hills open to the sun. Plant your pears, Daphnis: your grandchildren will pluck the fruits you have planted")

In this passage "the star of Caesar" presumably refers to the comet which had been seen after Iulius Caesar's death. Vergil, who was sympathetic to Iulius Caesar, tells us, that his star had come and gone and that his "reign", which had brought hope to the farming population in the years before 44 B.C. was now past ${ }^{92}$. Vergil prays for an end to the ongoing war and power struggle, and for better times, when Daphnis' grandchildren will gather the fruits that Daphnis has sown. Eventually, coexistence between the pastoral life and Rome may be possible, as omnia fert aetas, animum quoque (time steals everything, even our memory) (line 51). There is a mood of resignation as the two herdsmen proceed on their journey to the town in the depths of misery. Halfway through they see the tomb of Bianor. It is likely that the tomb suggests that the land is dead. Farmers, who cannot find green food for their animals, are forced to strip the trees: densas/agricolae stringent frondes (the farmers strip off the thick foliage). In these lines (58-61) Vergil shows us the loss of the pastoral environment, where even the last piece of shade has disappeared. Lycidas suggests singing, but Moeris' answer leaves him feeling helpless and forsaken, as he says in the last line of the poem: carmina tum melius, cum uenerit ipse, canemus (we will sing our songs better, when he himself has come). Their poetry is ineffective, and they cannot achieve anything on their own ${ }^{93}$. The master ipse - Menalcas - has to come. Is Vergil indicating in this early poem that he intends to put his poetry at the service of relieving the farmers' plight by exposing their miserable life? On the whole, in this Eclogue - and in many to come - Vergil comments bitterly and critically on the social disruption resulting from the land appropriations and the evictions of the farmers who belonged there.

92 Coleman (1981, 259). Coleman (1981, 266-267), brings up an interesting allusion in line 47: "Dione shared the cult of Dodona with Zeus, [...]. The unusual epithet for Caesar thus obliquely recalls that the Julians numbered Jove as well as Venus among their ancestors. However Dodona's prophetic doves were impotent in the face of armed force [as is referred to in line 13 of the present Eclogue] and the peace and prosperity heralded by the comet may be endangered likewise." (my emphasis).

93 Nauta (2006, 321-324) also links the power of poetry with that of the military and the political situation of the time. Nauta (2006, 321): "As in Ecl. 1, the dependence of bucolic poetry on the political realities, symbolised by the city, is at issue, and, as in Ecl.1, these realities take the form of confiscations of land", and Nauta (2006, 323): "he [Vergil] has written a bucolic poem showing how bucolic poetry is disrupted by its dependence on the political world." 


\subsubsection{Which River Did Lycoris See In Vergil's Tenth Eclogue? ${ }^{94}$}

The last Eclogue, the tenth, is generally seen as an expression of Vergil's friendship with Cornelius Gallus. Gallus, the soldier and writer of elegiac love poetry, is in Arcadia, probably temporarily - Clausen $(2003,288)$ suggests that Gallus is on leave -wasting away with unrequited love (indigno cum Gallus amore peribat) (line 10). Gallus seems to enjoy the commiseration and the attention from the shepherds and the presence of the flocks, and initially he wants to be part of bucolic life. In the end, however, he rejects this life and in lines 62-63 he says farewell to the pastoral lifestyle: iam neque Hamadryades rursus nec carmina nobis/ipsa placent; ipsae rursus concedite siluae. (Again neither Hamadryads [woodland Nymphs] nor even songs please me; farewell again, woods also). Boucher $(1966,94)$ states: “à notre avis l'on n'en peut conclure que Gallus ait été poète bucolique” (in our opinion, one cannot conclude that Gallus was a bucolic poet). As Putnam $(1970,378)$ remarks: "Gallus may pretend to embrace the pastoral spirit but his final decision is to renounce its aloofness and return to the battleground of love and war." It is difficult to know whether the poem is concerned with Gallus' poetical orientation because we don't have much work of his to establish what his choice of genre or genres was. However, it is unlikely that he changed to writing pastoral poetry ${ }^{95}$. At the end of the poem (lines 73-74) Vergil expresses his love and friendship for Gallus: Gallo, cuius amor tantum mihi crescit in horas/quantum uere nouo uiridis se subicit alnus (for Gallus, for whom my love grows hour by hour, as much as the green alder shoots up in a new spring).

94 The section on Ecl.10 was written in conjunction with Marc van der Poel, professor of Latin at Radboud Universiteit Nijmegen. Citations of this section should be as: Weeda, L. \& van der Poel, M.G.M. (2014). Which river did Lycoris see in Vergil's tenth Eclogue? In L. Weeda. Vergil's Political Commentary in the Eclogues, Georgics and Aeneid (pp.76-83). Berlin/Warsaw: De Gruyter Open. This section, with some minor adaptations, will also be submitted as a paper to a journal of classical studies.

95 For general commentary on Ecl.10, see: Boucher (1966, 16-26; 87-94); Clausen (2003, 288-292); Coleiro (1979, 268-280); Conte (1986, 100-129), reprinted in: Volk (2008, 216-244); Raymond (2013, 59-67); Williams (1968, 233-239). For Gallus' poetical orientation in Ecl.10 see Boucher (1966, 18; 25-26). Bessone (2013, 44-45) states: "In the family album put together by the Augustan elegists, [...] it is the line of succession Gallus-Tibullus-Propertius-Ovid that constitutes the canon of the elegists." Coleiro (1979, 269-271), with a discussion of much of the secondary literature on the subject. Gibson (2012, 172-186; esp. at 179-180) suggests that Gallus also wrote other poetry than the elegies for Lycoris, namely erotic poems with personal inclinations. This is far removed from the pastoral genre. Whitaker (1988, 454-458) concludes that Gallus did not write pastoral elegies. A similar problem of determining Gallus' poetical orientation due to the paucity of his extant work arises in the case of $E c l .6 .64-73$. In this passage Gallus is described as rising to Mount Helicon and receiving Hesiod's pipes. Clausen (2003, 200) and Raymond (2013, 65) interpret this as Gallus moving away from love-elegy to Callimachean aetiology. None of the modern scholars conclude from this passage that Gallus changed to pastoral poetry. See also discussion of Ecl.6 above. 
The above considerations are within the literary frame. Examining the Eclogues from a functional (political) point of view, I concluded that Vergil refers to aspects of the contemporary political situation in all the Eclogues (see the summary in section 3.1.3). In Ecl.10 Vergil does not only pay homage to his friend Gallus, but also gives his commentary on the contemporary political situation. This can be deduced from two passages: Ecl.10.14-17 and Ecl.10. 21-49. I will discuss lines 21-49 first, in particular the reference to the Rhenus in line 47. Vergil uses the word Rhenus only twice in his oeuvre, the other being in A.8.727 in his description of Aeneas' shield, where Rhenus refers to the river Rhine ${ }^{96}$. Contrary to all other commentators, who assume that in Ecl.10 he also refers to the Rhine, I intend to demonstrate that in the present poem Vergil describes a different river, the Rhenus (modern Reno) in Northern Italia. I will also assert that my functional interpretation of the name of the river gives the poem a very significant political content and meaning.

The poem as a whole is concerned with Gallus' unhappiness for his girlfriend Lycoris' departure. In lines 2-3 Vergil writes pauca meo Gallo, sed quae legat ipsa Lycoris,/carmina sunt dicenda (a few verses for my Gallus should be sung, but which Lycoris herself may also read). Vergil obviously hopes that she may change her mind after reading this Eclogue. Her very absconding, however, also refers to contemporary events. Lines 46-49, spoken by Gallus, give some clues.

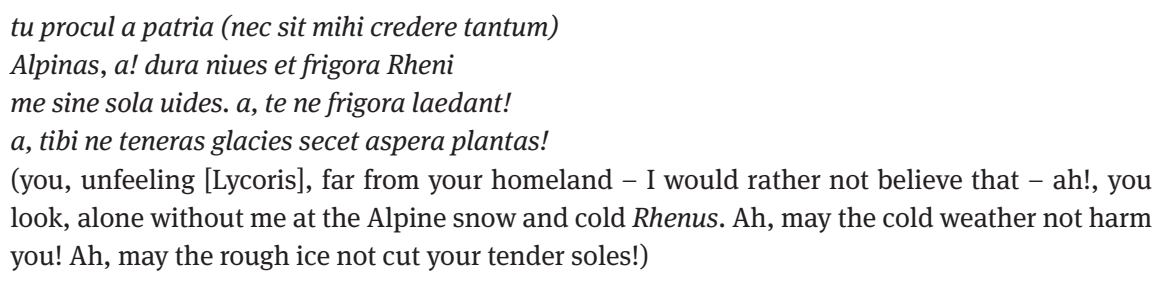

In his Commentary on Ecl.10.1-2, Servius identifies Lycoris, Gallus' love, with Cytheris, Mark Antony's mistress from 49-45 B.C. Ovid mentions Lycoris three times (Am.1.15.30, Ars 3.527, Tr.2.445), of which two refer directly to Gallus and Lycoris, but Cytheris does not feature in Ovid's work ${ }^{97}$. Cytheris was a popular and attractive actress. Whether the identification is correct or not, Vergil shows Gallus suffering when Lycoris (or Cytheris) runs off with another soldier. Apollo himself had told him

96 I scanned all Vergil's texts by means of Brepols' digital Library of Latin Texts. For Rhenus referring to the Rhine, see: section 4.1.1, and Weeda \& van der Poel, 2014.

97 Anderson, Parsons \& Nisbet (1979, 152-153); Boucher (1966, 16-26); Clausen (2003, 294); Gibson (2012, 175; 177-178); Raymond (2013, 60). Servius' text is from Thilo (1887, 118-119). Antony's relationship with Cytheris did not finish when he married Fulvia in 47 B.C. Plutarch (Antony.9.4) also mentions Cytheris as Antony's mistress. Syme (1978, 200-201) states however: “Cytheris as Lycoris, the notion is highly plausible. Yet gentle dubitation intrudes. The scholiasts in late Antiquity are capable of any fantasy or folly." 
in lines 22-23: 'Galle, quid insanis?' inquit. 'tua cura Lycoris/perque niues alium perque horrida castra secuta est' ("Gallus”, he [Apollo] said, "what are you raving about? Your beloved Lycoris followed another man through the snow and in rough camps"). According to Servius, it was Mark Antony whom Cytheris/Lycoris followed when she went to the Alpinas niues et frigora Rheni (Alpine snow and cold Rhenus) (line 47); this is generally interpreted as referring to the snowcapped Alps and the cold river Rhine. In the unlikely case that Cytheris joined Antony in Gallia, the reference to the river Rhine suggests that she went to the north-eastern part of Gallia. However, it is not plausible that she ever joined Antony in Gallia at all. After 49 B.C., when the two were lovers, Antony spent most of his time in Rome, where he was appointed by Iulius Caesar in different posts, among others, as magister equitum. The relationship between Antony and Cytheris finished in 45 B.C., and it was only after June 44 B.C. that Antony became governor (imperium proconsulare) of both Gallia Trans-alpina and Gallia Cis-alpina from 44-43 and of Trans-alpina only from 43-40 B.C. Anderson, Parsons \& Nisbet (1979, 125-155), in their discussion of the Gallus Fragment, found in 1978 in Qaşr Ibrim in Egypt, also mention this incongruity. They $(1979,153)$ write: "When Servius says that the other man is Antony (Ecl.10.1), the story does not easily fit his [Antony's] career" ${ }^{\text {"98 }}$. They subsequently consider a number of other men. According to Page (1960, 172-173) Lycoris is Cytheris, who "seems to have deserted Gallus for some officer on the staff of Agrippa, who led an expedition into Gaul and across the Rhine 37 B.C. (cf. lines 23, 46) while Gallus was on military service elsewhere (lines 44, 45)." Page simply assumed that Rhenus in line 47 is the river Rhine, without considering another option. Further, Gallus' military activities were not necessarily elsewhere, but could just as well have been in the Mantua region when he was in the area in 41/40 B.C.. Of course, it may be possible that Cytheris joined her ex-lover Antony in Gallia in 43 B.C., when, after his defeat at Forum Gallorum and Mutina (modern Modena) in April 43, he went to Gallia. In that case, the identification of the river Rhine is an anomaly, as Antony met with Lepidus who was staying in Gallia Narbonensis.

I submit that Servius' identification may be incorrect, and a woman named Lycoris was indeed Gallus' mistress, or that Lycoris is the name of the domina in his poems, like for instance Cynthia in Propertius' elegies (see Raymond 2013, 60). It is unlikely that Lycoris was a pseudonym for Cytheris. The only worthwhile extant fragment of Gallus' poetry begins with Gallus' lament of the wickedness of his mistress, named Lycoris. This fragment of one of Gallus' elegies is by far the oldest manuscript of Latin poetry. The archaeological site in Qaşr Ibrĭm has probably been occupied since 50-20 B.C.. The text of the relevant part of the Gallus Fragment is as follows:

98 My emphasis. 
tristia nequit[ia...] L Lycori tua [...]

fata mihi, Caesar, tum erunt mea dulcia, quom tu

maxima Romanae pars eri<s $>$ historiae

postque tuum reditum multorum templa deorum

fixa legam spolieis deivitiora tueis. etc.

(Lycoris, sad by your wickedness [...]

Caesar, my fate will then be kind to me, when you will have the largest share in Roman history, and I will read that after your return the temples of many gods are enriched being hung with your trophies)

Contrary to the view of Anderson, Parsons \& Nisbet (1979, 151-152), I suggest that Gallus' lines about Caesar and the "largest share in Roman history" refer most likely to Octavian ${ }^{99}$. Gallus expresses his confidence in the future achievements of the new man and refers to future peace and stability and his successes in foreign campaigns. He may have written these words after Philippi (October 42 B.C.) when he saw that Octavian gradually restored order. Hence, the fragment was probably not written in 45 B.C., as Anderson, Parsons \& Nisbet suggest, but after 42 B.C. (Philippi), in 41 or 40 B.C. ${ }^{100}$

Returning to Vergil, I suggest that his functional objective was to locate Ecl.10 in his native area, and thus Lycoris' identity was of no importance to him. As far as I can ascertain, all commentators hold the opinion that Lycoris travelled to the river Rhine, which I - as explained above - think unlikely. Therefore, I submit that he described the river Rhenus (modern Reno) in Northern Italia, the very same region where, in 4140 B.C., after Philippi, Gallus was engaged in his duties ${ }^{101}$. This would also indicate that Ecl.10 was written in 41 or 40 B.C., at about the same time as Eclogues 1 and 9, which fits in with the three poems referring to the process of land expropriations in

99 Contrary to Tarrant (2000, 172). See also the discussion of the fragment in Raymond (2013, 62-64).

100 Contrary to Gibson (2012, 184) who writes: "imagine a Roman love elegy [by Gallus] in the middle 40s B.C.” Anderson, Parsons \& Nisbet (1979, 153-154) considered also the likely dating of Ecl.10, and argue $(1979,153)$ that "the eclogue itself can hardly have been written later than 39 B.C.” If Ecl.10 describes the presumed desertion of Lycoris with an officer in Agrippa's army, the date of writing has to be later than 39 B.C., as Agrippa campaigned in Gallia in 37 B.C.. See also Boucher $(1966,19)$, who argues that "la dixième Eglogue, [...] doit dater vraisemblablement de 40-39" (the dating of the tenth Eclogue, [...] should probably be 40-39 [B.C.]).

101 Rhenus (modern Reno) in Northern Italia flows from the Apennines into the Po. The river passes Bononia (modern Bologna) and Mutina (modern Modena). Forum Gallorum and indeed Mantua (modern Mantova) are near. Pliny the Elder mentions the Reno in PLIN.3.118 and also in PLIN.16.161 (Mayhoff, 1967, 41) when he praises the reed of the Reno because none is more suitable for arrows (quando nullus sagittis aptior calamus quam in Rheno Bononiensi amne). Silius Italicus (Bauer, 1890, 193) writes about the Reno in his catalogue of the consuls' troops against Hannibal in SIL.8.590599 Vos etiam [...] parvique Bononia Rheni (You also, [people] of Bononia of the little Reno). Cf. Spalten $\neg$ stein $(1986,552)$.. 
Northern Italia ${ }^{102}$. It is likely that Vergil and Gallus met at that time and that this was the start of their friendship.

Thus the literal interpretation that the words of Ecl.10.22-23 (tua cura Lycoris/ perque niues alium perque horrida castra secuta est), and of Ecl.10.47 (Alpinas, a! dura niues et frigora Rheni) refer to Gallus' mistress - whose real name was Lycoris - should be seriously considered as expressing Vergil's intention. This Lycoris did not run off with a soldier to Gallia Trans-alpina, but she saw and probably crossed the river Rhenus (Reno), leaving an agreeable area for the inhospitable and snowy southern Alps. Romans considered Gallia Cis-alpina a civilized region, contrary to, for instance, Northern Gallia, or, even worse, Germania. The recognition of Gallia Cisalpina as a relatively advanced part of Italia also appears from the unofficial name of the province, togata, a reference to the Roman dress and as such a sign of Roman citizenship and adoption of the Roman lifestyle. This was very unlike the name of Gallia Trans-alpina, comata (long-haired), expressing the lasting barbarous habits of the inhabitants. Indeed, in 44-43 B.C., Cicero (Phil.3.13) called Gallia Cis-alpina flos Italiae, illud firmamentum imperi populi Romani (the flower of Italia, that support of the empire of the Roman people); these words suggest that the province is regarded by Cicero as part of Italia. However, according to Jenkyns (1998, 104; cf. Manuwald, 2007, 367) the people beyond the river Po (the Transpadani) "were at the margin of Italy in a literal sense; and though other Italians were as far from Rome, they alone were on a frontier, with barbarous and as yet unsubdued tribes perilously close in the mountains above." It is likely that Vergil describes Lycoris leaving hospitable and civilized Cis-alpina, and going north towards these "mountains above," the Alpine region. In lines 48-49, he describes Gallus' anxiety that Lycoris might have to endure the cold, or might cut her soles on the rocks of the Southern Alps, not those of the Northern Alps, as many scholars assume ${ }^{103}$. Who the soldier of lines 22-23, probably an officer, was remains a mystery.

The references to Gallus are an expression of Vergil's feelings of friendship and of his concern for his friend, who seems to perish as a result of his unrequited love. Vergil's regard of Gallus as a friend is the focus of this last Eclogue. But why are the poet's reference to Lycoris, her desertion of Gallus and the latter's loneliness so important? I will argue that Vergil is not just expressing his feelings of brotherly friendship, but also making a political point like in the other Eclogues.

102 In Ecl.6 Vergil is also concerned with the expropriations in his native area, but the dating of Ecl.6 is problematic. For the problems of chronology, see Perutelli (1995, 28-31, esp at 31), who states: "on the evidence that we have (not all cited here), a possible order of composition would be: 2, 3, 5, 4, 8, 7, 6, 9, 1, 10. But it would be presumptuous to defend to the end such a claim.” Anyhow, he places Ecl.6, 9, 1 and 10 as written last. Clausen (2003, xxii); Coleman (1981, 14-21).

103 Contrary to Jenkyns (1998, 185-186, esp. note 157) I "indulge the pleasing supposition that the elegiacs found at Qasr Ibrim were the work of Gallus himself.” Thus, Lycoris and her fate are important elements of the interpretation of Ecl.10. 
In this respect, lines 14-17, where Vergil locates Gallus in wild Arcadia with lonely crags and mountains - one of which is "icy cold Lycaeus" in line 15, the birthplace of Pan - may be relevant. In lines 14-15 Vergil describes hapless Gallus in a very "unpastoral" landscape: pinifer illum etiam sola sub rupe iacentem/Maenalus et gelidi fleuerunt saxa Lycaei (Maenalus [mountain of Arcadia] with his pines and the rocks of icy cold Lycaeus shed tears for him as he lay beneath a lonely crag). According to Jenkyns $(1989,27)$, "there is is no sign of anyone in the ancient world realizing that Virgil had discovered a spiritual Arcadia symbolic of pastoral," and (Jenkyns, 1989, 35) there is "no cause to regard the Arcadia of the tenth Eclogue as standing for the pastoral world"104. Why should Vergil place Gallus in an un-pastoral Arcadia? To show that Gallus gives up his ambition to write pastoral poetry? Coleman $(1981,295)$ argues in this way, stating (in the literary frame) that Vergil regards Gallus' predicament a result of Gallus' failed efforts to escape from misery by writing pastoral poetry. As mentioned above (note 95), it is very unlikely that Gallus ever wrote any pastoral poetry. He either stayed with his old genre, the love-elegy - omnia vincit Amor: et nos cedamus A mori. (Love conquers all: and let us all yield to Love) (line 69) - or changed to aetiological poetry. Or was Arcadia chosen (as Clausen, 2003, 288 hints at) because a pastoral setting could no longer be found in destroyed Italia or war-torn Sicily, even though Vergil invokes the Sicilian nymph Arethusa in the first line?

I suggest a different interpretation: in spite of Vergil's friendship for Gallus, the latter could not be shown as belonging to the pastoral world and as feeling comfortable in it, because he had been working as an official in Northern Italia at the time of the land expropriations. As stated in sections 3.1.1 and 3.1.2 (Ecl.9) above it is doubtful that Varus and Gallus were involved with the actual expropriations in the Mantua region. However, it is feasible that Vergil used their names to symbolise the actual involvement of high-ranking officials, without specifying exactly who was involved where ${ }^{105}$. It is also doubtful that Gallus made an effort to mediate between Vergil and Alfenus Varus in an attempt to exempt the entire area of Mantua, and that Vergil may have felt indebted to him ${ }^{106}$. Gallus worked at the time in some official capacity in the Mantuan area, and this may have been the cause that he was seen as someone who was closely associated with the men

104 Jenkyns (1989, 26-39, esp. at 27 and 34-36); Jenkyns (1998, 157-167). Paraphrasing Jenkyns (1989, 26-27): Arcadia as a pastoral landscape is not Vergilian, but was introduced around A.D. 1500. Clausen (2003, 288-290, note 4); Schmidt (2008, 16-47; reprint of original 1975 paper in Volk, 2008). Contrary to Gibson (2012, 178): "here Gallus is dying from the effects of love in the pastoral landscape of Arcadia." (my emphasis).

105 For Alfenus Varus' and Gallus' involvement, see notes 69, 81, and 91. Gold (2012a, 305) makes a similar point writing about patronage and the dramatis personae in a poem: "Is Propertius [for instance] describing an historical figure when he addresses Maecenas at some length in poems 2.1 and 3.9, [...], or is Maecenas transmuted into a symbol of important ideas in Propertius' poetry?"

106 For the supposed loss of Vergil's farm and attempt to mediate, see notes 66 and 91. 
who carried out the expulsions of the farmers, and had contributed indirectly to the destruction of the countryside. Thus, locating Gallus in Arcadia is Vergil's poetic act to symbolise Gallus' frustration and loneliness in a harsh and possibly hostile environment, and it is not a historic reality ${ }^{107}$. Boucher $(1966,94)$ hints at this when

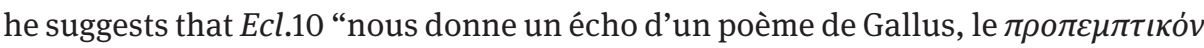

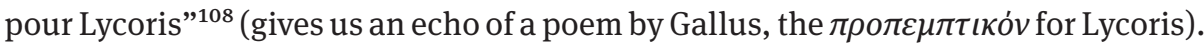
Boucher $(1966,93)$ states also: "L’hommage de Virgile est donc un hommage littéraire, rendu aux élégies de Gallus, constatant leur célébrité, le fait qu'elles sont devenues un modèle" (Therefore, Vergil's homage is a literary one, paid to Gallus' elegies, of which Vergil established their fame, and the fact that they became a model).

Boucher analysed the poem within a literary frame. However, approaching the poem within the functional frame, I suggest that Vergil pursued a different objective than just paying literary homage to Gallus. His loneliness is a result of the misfortunes of war: instead of Gallus enjoying the love of Lycoris, he stays behind alone as she is taken away by a soldier in the war. Gallus' fate is similar to that of the shepherd in Ecl.8.26 who has lost his girl (Nysa) to Mopsus (Mopso Nysa datur), whose name symbolizes a newcomer in the countryside, most likely a veteran soldier ${ }^{109}$. Like in Ecl.9.11-3, where Vergil wrote that poetry is no match for the tela Martia (the weapons of war), soldiers have won again both in Gallus' and Vergil's life. Ecl.10 shows an interesting ambivalence. By referring to the river Reno and Gallus, Vergil locates the narrative in his native area, and thus portrays the social and economic destruction caused by men like Gallus. At the same time, however, Gallus himself is the victim of a soldier, who steals his love. In Ecl.10 Vergil used Gallus' experience to voice his own concern about the continuing civil war having no prospect of being resolved. The evictions had destroyed the old social and economic structures, and the traditional farming population was impoverished. Instead of working their small farms, the crofters became virtually serfs to newcomers ${ }^{110}$. Like in Eclogues 1, 6 and 9, here too

107 Boucher $(1966,93)$ remarks that "Virgile place Gallus dans ce paysage arcadien au moment même où il lui fait déclarer qu'il est aux armées. Il s'agit là d’une logique toute bucolique qui permet de superposer à la réalité historique une autre forme" (Vergil locates Gallus in this arcadian landscape at the very moment that he lets him say that he is in the army. Here, it concerns a very bucolic logic, which permits to superpose on the historic reality another form). (emphasis is mine).

108 Boucher $(1966,93)$ contends that Lycoris leaving Gallus may have been a few years earlier, and (referring to PROP.1.8.7-8) that it is "ni certain, ni nécessaire que ce départ ait marqué la fin des amours de Gallus et de Lycoris" (neither certain nor necessary, that this leaving should have signified the end of the relationship of Gallus and Lycoris). It is nothing more than "an accident.” Propertius text reads: tu pedibus teneris positas calcare pruinas,/tu potes insolitas, Cynthia, ferre niues? (can you tread with your tender feet upon the rime on the ground, can you, Cynthia, put up with the unaccustomed snow?). Heyworth (2007, 31-32) states that this fits in with Ecl.10.46-49.

109 See note 79 and the discussion of Eclogues 5 and 8.

110 Martindale $(2000,114)$, who in his interpretation of $E c l .10$ focuses on the intertextuality rather than on the contextuality, reaches a different conclusion: "But none of this means that Virgil is solemnly debating 
Vergil gives his view on the expropriations and the expulsions in the Mantua region as well as on the involvement of a number of high-ranking officials to whom he alluded (Octavian in Ecl.1) or whom he mentioned by name (Varus in Ecl.6 and 9), thus denouncing the destruction and social upheaval caused by the civil war and its aftermath.

\subsubsection{Summary Of The Section About The Eclogues}

In two of the ten poems (Eclogues 2 and 3) Vergil touches only slightly upon the problems in the countryside, but in eight of them (Eclogues 1, 4, 5, 6, 7, 8, 9 and 10) he shows concern with major contemporary political matters. These eight are true bucolic poems, presenting a pastoral world where nature and man can be in harmony and where poetry can possess healing power worth more than political power or status. But Vergil also showed other, more sinister aspects: his pastoral world was threatened or had already disappeared, not through mismanagement or indifference of the farmers, but through forces from outside. Exploring the relationship of Vergil's political stance on the one hand and the poetic nature of the Eclogues on the other, Tarrant $(2000,173)$ states: "The Eclogues are paradoxically both the work in which contemporary events are most pervasively present and the one in which they are most thoroughly transformed to subordinate them to a poetic context." He (2000, 173-174) also contends that the historic events mentioned in the poems, such as the land confiscations, Philippi, the consulship of Pollio and the pact of Brundisium, "are translated into pastoral terms that soften and distance their topical quality, and that defeat efforts to see direct equivalents between pastoral figures and historic persons" (Tarrant 2000, 173-174). I argue however, that many ostensible "pastoral figures" and events are deliberate functional references to contemporary topics, and thus assume a political significance: for instance, Tityrus and Meliboeus in Ecl.1, Mopsus in Ecl.5 and Ecl.8, Pasiphaë in Ecl.6, Thyrsis in Ecl.7 and the tomb of Bianor in Ecl.9. The significance of the Eclogues is that Vergil wrote from his personal knowledge, referring not just to an unnamed general threat, but to a very specific one, namely the land confiscations. These were not vague confiscations somewhere in Italia, but occurred in his own region, near Mantua. For instance, the poet refers to the expropriations and the expulsions in the Mantua region and the involvement of well-known men (who probably also symbolize high-ranking officials in general) in Eclogues 1, 6, 9 and

the merits and demerits of different genres, let alone acknowledging the failure of his own bucolic art," (with this I agree fully). He continues: "We could say that Virgil is expressing poetic and erotic solidarity with Gallus, with consummate art is helping him court his docta puella." I would add: and commiserates Gallus, who is suffering from the vicissitudes caused by war, as so many others. Harrison (2007, 74) notes the: "generic enrichment" showing the duality between a "guest" love-elegiac embedded in a "host" pastoral poem. 
10. In particular, he mentions: Alfenus Varus (Ecl.6.6-12 and Ecl.9.26-29) and Gallus (Ecl.6.64 and Ecl.10.1-10, Ecl.10.22-23 and Ecl.10.72-73) and indirectly even Octavian (Ecl.1.42-43). Of course, Vergil also pointed out the effects of the expropriations in general. Four poems contain a description of the indifference of, and exploitation by, the new owners (Eclogues 5, 7, 8 and 9). The threat to the pastoral life (Eclogues 2, 3 and 9), the destruction of rural communities (Eclogues 6, 8 and 9), and the disappearance of essential values (Eclogues 3 and 8) are also described. Finally, in Ecl.4 - a poem expressing the poet's hope for peace and for the return of order to the farming lands of Italia - Vergil looks to the future, when stability will be achieved as Antony - and not Octavian - brings peace to Italia. In Ecl.4, he introduces in his view on the preferred constitutional arrangements when the war is over, namely a hereditary form of nonelected political authority and one-man rule.

Vergil gives his commentary on contemporary political and social matters in many more Eclogues than is generally recognised. Boyle's interpretation of the book from the perspective of human psychology is an interesting supplement to our argument which is from the perspective of Vergil's political views ${ }^{111}$. Boyle $(1986,33)$ argues that Vergil's

hopes for a better, a less misshapen world, his hopes that urban man might relearn the Theocritean values he has forsaken and, embodying the pastoral ethic in thought and action, bring a just, fecund and joyous society once more into existence, are hopes the poet expects to remain unfulfilled. [...] But, as Virgil clearly perceives, the power of the artist to teach requires man's willingness or even ability to learn, his ability to subjugate and to control the potentially despotic forces in his psychology which drive out rational thought - sexual passion, ambition, greed, the lust for power, wealth or war - forces which are a kind of psychological madness, which deform, derange and destroy.

As he harboured great love for "old Italia", the land of farmers, Vergil was embittered and very concerned about the way the traditional social structures were being destroyed, and the way smallholders were being expelled from their farms. Vergil had personal knowledge of lawlessness, which he regarded as being a result of the long period of never-ending civil war, for which he held the leaders of the different factions responsible. At the time he wrote the Eclogues (between 42 B.C and 35 B.C) he kept his distance from Octavian and showed himself to be critical of his actions in Eclogues 1, 6, 7, 8 and $9^{112}$.

111 See also Martindale $(2000,110)$.

112 See also note 70. Contrary to Nauta (2006, 301-332), who considers "panegyric as a central component of his Bucolics," I see Vergil's critical attitude towards Octavian and some of his associates as central. A brief summary of our differences follows. Ecl.1. Nauta: praise of Octavian; my view: praise of Octavian (deus), but critical of Octavian as responsible for expropriations. Ecl.3. Nauta: praise of Pollio's poetry; my view: praise of Pollio indeed, but critical of the destruction of traditional values. Ecl.4. Nauta: praise of unborn boy; my view: praise of kingship. Ecl.5. Nauta: praise of Iulius Caesar; my view: critical of political strife and arrogance of new owners. Ecl.6. Nauta: praise of Gallus' poetry; my view: poem is about Vergil's political orientation and is critical of Octavian's officials. Ecl.7. Nauta: not mentioned; my view: critical of new landowners and social developments. Ecl.8. Nauta: praise of 


\subsection{The Georgics: A Didactic Poem With Political Views}

In the previous section I examined each Eclogue separately. This is possible as the book consists of discrete poems which can be studied as individual entities. This is not the case for the Georgics, the subject of this section, and for the Aeneid, which will be explored in the next chapter. Therefore, I will select from the Georgics and the Aeneid only the passages that in my view are relevant for the study of Vergil's political opinions.

Vergil wrote the Georgics between 35 B.C. and 29 B.C., having been invited to join Maecenas' circle of friends a few years before. As the opening lines show, the four books were dedicated to Maecenas: QUID faciat laetas segetes, quo sidere terram/uertere, Maecenas, [...]// conueniat [...],/hinc canere incipiam. (What makes the crops full of joy, in which season, Maecenas, it is right to turn the soil, hence I shall begin my song ${ }^{113}$.

It is a truism to say that the Georgics is more than a didactic poem about land, trees, cattle and bees. It also has a very visible socio-political content, as the opening passage and the final lines exemplify. After addressing several of the gods, Vergil wrote in (G.1.24-28):

tuque adeo, quem mox quae sint habitura deorum

concilia incertum est, urbisne inuisere, Caesar,

terrarumque uelis curam, et te maximus orbis

auctorem frugum tempestatumque potentem

accipiat;

(and especially you, Caesar, of whom it is not known yet which councils of the gods shall soon require you, whether you wish to govern cities and look after our lands, and that the great circle of lands may receive you as the provider of the fruits of the earth and master of the seasons)

More than two thousand lines later (559-562), in what is almost the closure of the book of Georgics, he writes:

Haec super aruorum cultu pecorumque canebam

et super arboribus, Caesar dum magnus ad altum

fulminat Euphraten bello uictorque uolentis

per populos dat iura uiamque adfectat Olympo.

(These lines about the care of fields, of cattle, and of trees I sang, while great Caesar thundered in war as far as the deep Euphrates and as victor gave laws to willing nations, and entered on the path to the Olympus)

Octavian; my view: critical of Octavian for the destruction of traditional social structure. Ecl.9. Nauta: praise of Varus and poetry disrupted by political world; my view: critical of social disruption. Ecl.10. Nauta: entire poem devoted to Gallus, praise not clear; my view: Vergil commiserates Gallus. For the arguments in support of my view see the appropriate discussions in section 3.1.2.

113 Harrison (2007c, 136-167); Mynors, 2003; Thomas, 1988a; Wilkinson, 1997. 
Immediately after the opening lines there is a reference to Caesar, Octavian, in lines 24-28. After he has announced in lines 1-5 that he will sing (canere incipiam) about agriculture, Vergil praises Caesar and places him among the gods of the future. Many lines later, he closes his didactic poem by saying that he has sung (canebam) about "the care of fields, of cattle and of trees." However "he has been taking it easy in a cultured resort with a Greek name [Parthenope, Naples; G.4.563-564]. Caesar, on the other hand, has been working wonders........]. Virgil is concerned with the relationship of poetry and the traditional Roman values, as, on the view here put forward, he has been all through the poem" (Griffin, 1979, 72). In many ways, in the Georgics, Vergil offers views on the state of affairs in Rome. Wilkinson $(1997,56-68)$ discusses the relationship between the Georgics and Vergil's literary predecessors, among others, Hesiod and his Works and Days. Although it is likely that Vergil owes a literary debt to Hesiod, I agree with Wilkinson's $(1997,60)$ assessment of the relationship ${ }^{114}$ :

The Works and Days is far from being a Georgic. [...] What it could teach Virgil was that a didactic treatise could be a vehicle for moral, religious and philosophic ideas, and at least intermittently for poetry. [...] Even if he began with the idea of following Hesiod, Virgil soon came to realise that he was engaged on something larger and warmer, a panorama of rural life in Italy, with all its social and philosophical implications.

This raises the question of whom the book of Georgics was written for and what kind of farmer Vergil had in mind. It is evident that only a highly sophisticated man could have appreciated the poem. This was probably not the crofter, who, together with his family, worked a small plot of land, but rather the absentee landlord or the owner of the large estate who lived in Rome or another city. These men were generally no active farmers themselves, but they were sufficiently knowledgeable and did not need to be taught the basics of farming. Italia at large was an agricultural society and many people had ties with the land (Schrijvers, 2004, 7-15; Wilkinson, 1997, 4955, 67-68). Although Vergil shows that he knows the technical side of farming on a smallholding, the Georgics is not a handbook for farmers as the De agricultura of M. Porcius Cato (234-149 B.C.) or the work in twelve books Rei rusticae libri of Iunius Moderatus Columella (first century A.D.). It is not as comprehensive as the $D e R e$ Rustica of M. Terentius Varro 'Reatinus' (116-27 B.C.), which presumably exerted a great influence on the Georgics. Vergil himself remarks at different occasions that he has no wish to be complete. In the second proem to book 2 (42-44) he writes: non ego

114 Thomas (1988a, 4-11) and Wilkinson (1997, 3-19, 56-68) give an impressive list of Vergil's literary predecessors. Apart from Hesiod, Aratus, Theocritus, Callimachus, Lucretius, and Varro (Wilkinson), Thomas mentions also Aratus, Theophrastus, Nicander, Eratosthenes, Catullus, Gallus, Varius Rufus and some self-reference to his Eclogues. Mynors (2003, 325-333) gives the Greek texts of relevant passages by Eratosthenes, Aratus and Aristoteles. Wilkinson presents a relevant choice of secondary literature. (italics in the quotation of Wilkinson are mine). See also Harrison (2007c, 136-137). 
cuncta meis amplecti uersibus opto,/non, mihi si linguae centum sint oraque centum,/ ferrea uox. (I myself do not wish to consider everything within my verses, even if I had hundred tongues and hundred mouths, and a voice of steel). And in book 4, 147-148 he says: uerum haec ipse equidem spatiis exclusus iniquis/praetereo atque aliis post me memoranda relinquo. (But these matters I for my part pass by due to lack of space, and I leave these to others after me to record). Vergil expresses a desire for brevity not for the sake of restricting his agricultural teaching, but because he wants to send out a different message. According to Wilkinson $(1997,3)$ the didactic is the book's "ostensible genre: it was deceptive and has abundantly deceived." The didactic is but a background to his description of his love for the countryside and his political and social views, which will be discussed below.

The limitations of his agricultural lessons also show in another aspect. In book 1, which deals with field crops Vergil concentrates on cereals only, in book 2, which is about trees he writes only about vine, with a few lines on olives. Book 3 is about cattle, horses, sheep and goats and no other animals are mentioned. Finally, book 4 is only on bees.

The first book begins with a proem to the whole work in which Vergil presents the contents of the four books and addresses Maecenas (Mynors, 2003, 1-99). He invokes the twelve divinities of agriculture and from line 24 onwards he asks Octavian, already deified, to give his assent to his bold enterprise (line 40: audacibus adnue coeptis) and to share Vergil's pity on the poor farmers (line 41; mecum miseratus agrestis). Vergil refers here to the desolate state of the free farmers on their smallholdings, and asks Octavian to work towards an improvement of their fate.

In the following part of book 1 (121-146) Vergil voices his belief that good husbandry is hard work, which the Father (Iuppiter) himself has desired. In Vergil's view "men depend on their own efforts, though under the aegis of helpful gods like Ceres (1.147)" (Galinsky, 1996, 95). It is not as easy as in the mythical Golden Age: however hard one toils one has to cope with weeds and insects, and man must learn to use tools. In G.1.121-123 he writes:

pater ipse colendi

haud facilem esse uiam uoluit, primusque per artem

mouit agros, curis acuens mortalia corda

(The Father himself has desired that the path of taking care of fields should not be easy; and he was first to begin the art of farming, sharpening men's minds by caring)

In this passage, Vergil weaves his Hesiodic inspiration in his teaching about farming. I use the words "Hesiodic inspiration" advisedly. In the Works and Days man's hard labour is a punishment for Prometheus' theft and puts an end to the mythical Golden Age. Vergil's belief is different from Hesiod's. Vergil sees human toil as a god given necessity, and the new Golden Age is the result of this labour. The section about good husbandry is then followed by the farmer's calendar. Vergil explains the influence of the stellar constellations on the weather, as well as Eratosthenes' 
five zones of the earth and the need to observe the seasons for reaping and sowing. The devastation caused by a heavy storm is described. After this follows a section about the weather signs and the need to watch out for these in order not to be caught unawares.

In the finale of the first book (from line 461 onwards) Vergil changes the subject abruptly to contemporary political matters, namely the death of Iulius Caesar and the future of Italia, the horror of war, and the ensuing destruction of the land. First, we hear of the portents after Iulius Caesar's death, but after line 489 the picture changes to the ravages of the civil war at Philippi and other places. It is generally assumed that book 1 was completed at the end of 36 B.C. or early in 35 B.C.. Wilkinson presents a coherent argument that the finale was written at the same time $\mathrm{e}^{115}$. The political situation at that time was that Antony was far away on the Eastern front and that Octavian had just defeated Sextus Pompeius and entered Rome in triumph. In those heady days Vergil described the destructions of the civil war in lines 489-497, in a scene which a war poet could have applied to Northern France or to Ypres in World War I. Vergil prays that Octavian will restore peace and that the land can be farmed again. I will quote two passages from the finale. Firstly, the passage about the ravages at Philippi and the surrounding area, G.1.489-497 (Mynors, 2003, 94-99). Vergil probably refers to the second battle of Philippi of $23^{\text {rd }}$ October 42 B.C., three weeks after the indecisive first:

ergo inter sese paribus concurrere telis

Romanas acies iterum uidere Philippi;

nec fuit indignum superis bis sanguine nostro

Emathiam et latos Haemi pinguescere campos.

scilicet et tempus ueniet, cum finibus illis

agricola incuruo terram molitus aratro

exesa inueniet scabra robigine pila,

aut grauibus rastris galeas pulsabit inanis

grandiaque effossis mirabitur ossa sepulcris.

(no surprise that Philippi saw again Roman armies fight each other with equal arms; and the gods did not think it monstrous that Macedonia and the wide plains of the Haemon grew twice fat with the blood of our men. To be sure, a time will come when a farmer in those lands, as he works the ground with his curved plough, will find javelins corroded with rough rust, or with heavy hoes will strike against empty helmets, and will be astonished by great bones when graves have been dug up)

115 Wilkinson $(1997,161)$. His argument is: "The finale follows quite naturally and embodies the emotions of the day. Virgil would not feel called upon to modify it later. I much prefer this conception to the idea [Fraenkel's idea in his book entitled Horace, 287-288] that the lines about Caesar were inserted after Actium.” 
The second passage is the prayer in G.1.498-514 that Octavian will restore order:
di patrii, [...]
hunc saltem euerso iuuenem succurrere saeclo
ne prohibete. [...]
iam pridem nobis caeli te regia, Caesar,
inuidet atque hominum queritur curare triumphos,
quippe ubi fas uersum atque nefas: tot bella per orbem,
tam multae scelerum facies, non ullus aratro
dignus honos, squalent abductis arua colonis,
et curuae rigidum falces conflantur in ensem.
[...]; saeuit toto Mars impius orbe,
(Gods of my country, at least do not hinder this young prince from helping a ruined world. Long enough, Caesar, the heavenly court begrudges you to us, and complains that you trouble yourself about human triumphs, and right and wrong are here reversed: so many wars over the world, so many forms of wickedness, not any proper respect for the plough, our lands, where the farmers have been removed, are neglected, and curved pruning hooks are melted into a hard sword; unholy Mars rages throughout the world)

Dominik $(2009,126)$ says this about this dramatic closure of the first book:

As Vergil specifically observes, war destroys respect for the plough: the lands lie in waste and pruning hooks are forged into straight blades (G.1.506-8). The Georgics is actually more of a poem about the frenzied proclivity for battle and the intrusion of politico-militaristic values into the agrarian landscape than it is an example of the delicate pastoral aesthetic.

Book 2 is about trees, especially about the vine (Mynors, 2003, 101-177). After having addressed Bacchus and Maecenas and made the point that he has no desire to be complete (line 42), Vergil describes the art of propagation and again briefly mentions, in lines 61-62, one of his favourite themes, hard labour: scilicet omnibus est labor impendendus, et omnes/cogendae in sulcum ac multa mercede domandae (of course, one has to work on all this, and all must be brought together into a trench, and tamed at great cost). This is followed by a catalogue of wines and of riches from Arabia, India and China, such as incense, ebony and silk. Then, Vergil sings the praises of his homeland in the passage called laudes Italiae (lines 136-176). He uses in G.2.140-143 a functional model referring to the peaceful nature of Italia. According to Harrison (2007c, 142): "This [passage, lines 140-142] can be taken as more than simple praise of Italian agriculture as free from mythological horrors." He reads the lines in a literary frame, namely that "the rejection of Jason's mythological ploughing in favour of Italian agriculture is also a rejection of traditional mythological epic for the Georgic" (Harrison 2007c, 143). I read the passage as a functional reference to the peace of Italia: never was Italia's land, unlike Colchis, ploughed by Jason's fierce bulls harvesting soldiers carrying lances (uirum seges horruit hastis). Instead, serene and untroubled Italia was ploughed by gentle oxen. In the preceding lines (G.2.136-138), the poet also tells us that there is no land like Italia: 
Sed neque Medorum siluae ditissima terra nec pulcher Ganges atque auro turbidus Hermus laudibus Italiae certent,

(But neither the land of the Medes, very rich with forests, nor the beautiful Ganges, nor the Hermus, thick with gold, may vie with Italia's glories)

According to Harrison (2007c, 140), "the collection of place names gives a generally Oriental atmosphere, as commentators note, but he conjunction of Medes, [etc] recall the campaigns of Alexander the Great." Harrison also states that from this follows that "the poetic praises of territories associated with Alexander in Choerilus and other poets of Alexander-epics are inferior to the praises of Italy and Caesar/Augustus in the Georgics itself" (Harrison 2007c, 141). However, Vergil also makes a political point in his reference to Alexander: Italia needs a strong military and political leader - as great as Alexander was - who will resolve the internal and foreign stalemate and restore Rome's glory. I suggest that Vergil had Octavian in mind, and not Antony, who had been engaged in the East, as he mentions Caesar in lines 170-172: et te, maxime Caesar,/qui nunc extremis Asiae iam uictor in oris/imbellem auertis Romanis arcibus Indum (and you, almighty Caesar, who, already victorious on Asia's farthest borders, you just now drive the unheroic Easterling from the Roman heights). The laudes Italiae (lines 136-176) were presumably written in 30 B.C. as can be deduced from the above lines 170-172 referring to the time immediately after Actium when Octavian went to Alexandria and after the deaths of Antony and Cleopatra campaigned in Syria. In 30 B.C. the worst of the civil war was over, and Vergil expresses his hope and confidence that the glory of a unified Italia will finally arrive. Contrary to Harrison's (2007c, 138) view, I contend that Vergil is not "firmly rooted [...] in the anti-Oriental and pro-Italian propaganda of the period surrounding the battle of Actium." Rather, he is stating his belief that Octavian might be the right man to repulse the Parthian danger. If this happened, the land would be restored and people would enjoy peace and tranquillity again. This stability, however, had to be founded on military strength. The passage contains many lines which, on the one hand, praise Italia as a fertile land with many riches, and on the other refer to her as having bred a genus acre uirum (a fierce race), two sides of the same coin.

In the next part, the poet turns to the different soils of Italia and its suitability for different trees. The planting, manuring and caring of vines are discussed. Naturally, the theme of hard labour is explored again. A short section on trees that require less care concludes this part.

In the final part of the second book (lines 458-542), Vergil approaches a major political issue. In the first thirty-seven lines (458-494) Vergil portrays farmers, of whom Mynors $(2003,162)$ says: “Agricolae are indeed much blessed. They are not what the world calls rich, but they live in peace and in pleasant places among honourable neighbours.” In G.2.458-460 Vergil writes: 
O fortunatos nimium, sua si bona norint,

agricolas! quibus ipsa procul discordibus armis

fundit humo facilem uictum iustissima tellus;

(o farmers, exceedingly fortunate, if they just know their blessings, for whom, far from the arms of disagreeing men, the most righteous earth, brings forth from her soil an easy nourishment)

According to Mynors $(2003,162)$, the words iustissima tellus can be interpreted as a functional reference to "a traditional view," namely that "your ground will always repay what you have entrusted to it, and more." This view is expressed by, among others, Aristotle. Although many farmers may have thought differently, Vergil presumably wants to capture the age-old traditions still to be found in farmer's work. In G.2.490-494, Vergil summarizes this happy state of the farming population:

\author{
felix qui potuit rerum cognoscere causas \\ atque metus omnis et inexorabile fatum \\ subiecit pedibus strepitumque Acherontis auari: \\ fortunatus et ille deos qui nouit agrestis \\ Panaque Siluanumque senem Nymphasque sorores. \\ (fortunate is the man who has been able to understand the causes of events, and who has crushed \\ under his feet all fear and rigorous fate, and the noise of greedy Acheron: fortunate also is the man \\ who knows the gods of the country, Pan and old Silvanus and the sisterhood of the Nymphs)
}

Pan, Silvanus and the Nymphs together are a functional model for the country life. Mynors $(2003,169)$ puts it rightly: "If the deities were to be taken to represent a literary genre, it would be bucolic rather than didactic poetry, for all that they appear in the proem to Book 1; they stand for the idyllic country life of which a description follows, rather than for vigorous farming activity."

From line 495 onwards Vergil recounts the pursuits of the man in the city, and through these introduces political issues. The city is where the political action is, resulting in war and civil strife and destroying the peace of the farmers' life. In G.2.495-498 one reads:

\footnotetext{
illum non populi fasces, non purpura regum

flexit et infidos agitans discordia fratres, aut coniurato descendens Dacus ab Histro, non res Romanae perituraque regna;

(people's high office has not influenced the man, nor the purple of kings, and dissension troubling treacherous brothers, nor the Dacians coming down from the conspiring Danube, nor Roman activities and kingdoms which will be destroyed)
}

These lines describe the contemporary political troubles. The discordia fratres refers most likely not to domestic strife, but, as Mynors (2003, 170) states, to the situation in Parthia (Tiridates and Phraates IV), "whose dissensions were dealt with by Octavian in 30 B.C.". Dacus refers to the Dacians who "had sided with M. Antonius against Octavian, and continued to cause trouble after Actium". 
Through these examples Vergil contrasts the world of high office with that of the harmonious farmer's life described in the previous and also in the following lines. Horace expresses similar feelings in the Ode to Maecenas (Carm.3.29), where he urges the latter to forget Roman politics and come to his estate near Tibur to relax with a good wine (see section 2.3). The farmer's life, as Vergil portrays this in G.2.498-503, is different. A man of the country does not suffer from pity for the needy, as there are no poor. He also does not envy the rich, as he has enough. He is neither immune to pity and envy nor does he stand above it: these feelings simply do not arise when one lives in the blessed country.

neque ille

aut doluit miserans inopem aut inuidit habenti.

quos rami fructus, quos ipsa uolentia rura

sponte tulere sua, carpsit, nec ferrea iura

insanumque forum aut populi tabularia uidit

(the man has not felt pity for the needy, nor envy of the rich. He plucked the fruits, which his branches and his own fields have voluntarily and freely born; and he did not see the iron laws, the raving Forum, or the public record office)

This is followed by yet more praises of country life, culminating in G.2.523-531, especially in lines 524-527, which contain, according to Mynors $(2003,174)$, "two good tests, to see if farm animals prosper."

ubera uaccae

lactea demittunt, pinguesque in gramine laeto

inter se aduersis luctantur cornibus haedi.

ipse dies agitat festos

(cows droop udders full of milk, and on the rich pasture fat young goats tussle, horns facing horns. The farmer himself has a day off)

The proofs of a well-managed farm are when cows produce plenty of milk, the goats are healthy and the farmer has time for a day off.

In the last eleven lines (G.2.532-542) of the book, Vergil concentrates on Rome. G.2.532-534 and 538-540 say:

hanc olim ueteres uitam coluere Sabini,

hanc Remus et frater; sic fortis Etruria creuit

scilicet et rerum facta est pulcherrima Roma, [...]

aureus hanc uitam in terris Saturnus agebat;

necdum etiam audierant inflari classica, necdum

impositos duris crepitare incudibus ensis.

(the old Sabines lived such a life once, and Remus and his brother; thus, indeed, Etruria grew strong, and Rome was made the most beautiful place to be

[...] golden Saturn lived such a life on earth; and not yet had one heard the war trumpets blare, not yet the clanging of the swords, as they were laid upon the hard anvils) 
Mynors (2003, 175-177) argues that Sabini, Remus et frater, and Etruria portray the foundation of Rome. Vergil points out that in the era just before and after the foundation, when Saturn lived on earth (line 538), Rome herself was the most beautiful place to be. This was also the time of the king of Latium, with whom Saturn was identified and whose sole surviving descendants are those who till the ground. Thus the farmers in the country uphold the real Roman mores and form the backbone of society. What has gone wrong? Vergil's answer is in lines 539-540: the war trumpets and the forging of the sword.

Although the poet devotes the greater part of the second book describing agricultural practices, something like one fifth of the book is concerned with the praise of Italia (lines 136-170), and - particularly towards the end - the ideal country life and the differences between the country and the city (lines 458-540). These differences do not just represent the antithesis of peaceful country life versus the stress of city life, but go deeper. Vergil uses them to refer to the contemporary political situation. Wilkinson $(1997,92)$ interprets the passage as follows: "to relieve its length the finale is presented as a triple contrast: between city luxury (460-6) and country sufficiency (467-74); between scientific philosophy (475-82, 490-2) and knowing the gods of the country (483-9; 493-502); and between worldly ambition (503-12) and innocent country pursuits (513-40)." However, the contraposition in this lengthy passage goes much deeper and is, in essence, political. The contrast is not between the hectic life of the city dwellers and the happiness of rural life, but between centralized power and armed conflict on the one hand, and stability and self-sufficiency on the other (Mynors, 2003, 162-177). Vergil deplores not only the destruction of the traditional country life, like he did in the Eclogues, but he also points out that the responsibility for this lies with the political elite, which has been waging a civil war and fighting for power for decades.

Book 3 is concerned with animals: horses and cattle in the first part and sheep and goats in the second (Mynors, 2003, 178-257; Wilkinson, 1997, 92-99, 165-170, 323324). Apart from the proem (lines 1-48) and a short transition to the second part (lines 284-294), the whole of the third book consists of a "didactic" exposé about the care of animals. Vergil provides the political context in the proem. The proem shows Pindaric influences, and the poet says in lines 12-16 that he will erect an imaginary temple (Mynors, 2003, 181). The temple will be built beside the Mincius, Mantua's river. In line 16 Vergil says: in medio mihi Caesar erit (in the middle [of the temple] I will have Caesar). The poet will offer his verses to Octavian: verses, which he, in Pindaric fashion, describes as a hundred horse-drawn chariots (lines 17-18): illi uictor ego et Tyrio conspectus in ostro/centum quadriiugos agitabo ad flumina currus (In his [Octavian's] honour I, a victor striking in Tyrian purple, will drive a hundred chariots drawn by four horses beside the river [Mincius]). Mynors $(2003,181)$ suggests that either these verses, modelled on Pindar's epinikian poetry, are not referring to victories in athletic festivals, but to the "victory of Roman poetry over Greek," or that Vergil "may also have been thinking of the latest foundation in the Greek series [of games], 
the Actia instituted by Octavian when he refounded the temple of Apollo at Actium/ Nicopolis after his victory on 2 September 31 B.C.” (Mynors, 2003, 181-182). My own interpretation of these lines is much closer to this second suggestion. This Pindaric setting is a suitable background to praise Octavian. Through the functional reference to Mantua, Vergil poetically links the future emperor with his beloved part of rural Italia. This also fits in with the last part of the proem describing the carvings in gold and ebony on the temple doors: a celebration of the triumphs of the Romans under Octavian. Lines 26-29 tell part of the story, that of Actium and Antony and Cleopatra.

\author{
in foribus pugnam ex auro solidoque elephanto \\ Gangaridum faciam uictorisque arma Quirini, \\ atque hic undantem bello magnumque fluentem \\ Nilum ac nauali surgentis aere columnas. \\ (I will engrave on the doors in solid gold and ivory the battle of the people of the Ganges and the \\ army of conquering Quirinus [Octavian], and there also the great Nile flowing and swelling with \\ war, and towering columns made of the brass [from the beaks of captured] ships)
}

This passage concerns the final defeat of Octavian's last adversaries, Antony and Cleopatra. The Gangaridum represent the Oriental forces that fought under Antony at Actium, and uictoris Quirini refers to Octavian (Harrison, 2007c, 149-156; Mynors, 2003, 184). At the time there was much talk of giving him that name in honour of his achievements; eventually this became Augustus. The "columns made of the brass from the beaks of captured ships" came from the captured Egyptian fleet. Some were set up in the Capitol, some in the temple of Divus Iulius (Wilkinson, 1997, 169). In the following lines, other triumphs of Octavian are mentioned, both in the East and in the West. In the proem, Vergil expresses the possible return to normality with Octavian as the bringer of peace and prosperity, which are the conditions necessary for the farmer to once again concentrate on the care of his animals. The latter is described from line 49 onwards. In lines 40-48, Vergil introduces a hunting scene which forms a somewhat curious interlude to the care of horses, cattle and sheep. Harrison's (2007c, 156) literary interpretation that "here as elsewhere in the Georgics we find a strong sense of impending literary ascent, with the promised military epic [the Aeneid?] looming large" is plausible: it may be one of the poet's reaffirmations that he will write an epic. Yet, in this passage as a whole Vergil focuses on Actium and its aftermath, as Octavian's victory has removed the most significant threat. This is a statement of Vergil's relief that the future looked better.

From G.3.49, Vergil continues with cattle and horses and their breeding. In line 103, he refers to the animals' sexuality, their grief at defeat and their pride in victory. After this, a lengthy passage (lines 157-283) follows about the rearing and training of calves and foals, and about the danger of the sexual preoccupation of cattle and horses, which is a threat to their efficiency. In the second half of book 3 (lines 284-566) Vergil is concerned with sheep and goats and their care in winter and in summer. Sheep and goats provide men with wool and milk. But dangers also loom: thieves, 
wolves and snakes. Man has to look after his sheepdogs to protect the animals and the poet gives more good advice for the safety of the flocks. Vergil finishes book 3 with the horrible deaths of animals due to an epidemic plague in Northern Italia.

Vergil's commentary on political issues in the third book is limited, the leading theme being the effort required for the breeding and care of horses, cattle and sheep. However, Vergil does make a political point, which is his hope that normality returns, and that the farmer can farm again. If Italia wants to regain its traditional values and rebuild some economic order, peace has to be reinstated.

Book 4 of the Georgics has three parts (Mynors, 2003, 258-324; Wilkinson, 1997, 100-120): in the first (lines 1-280), Vergil is concerned with beekeeping: in the second (lines 281-314), he gives a short interlude about what to do when a swarm falls ill and dies: in the third (lines 315-558), he relates the Aristaeus epyllion proper. At first sight this epyllion seems a rather strange closure of the Georgics, and there has been much speculation about Vergil's motives for including it. In his commentary on G.4.1, Servius says: sane sciendum, ut supra diximus, ultimam partem huius libri esse mutatam: nam laudes Galli habuit locus ille, qui nunc Orphei continet fabulam, quae inserta est, postquam irato Augusto Gallus occisus est (It is known of course that, as I said above, the final part of this book was altered: for the praises of Gallus stood there where now the story of Orpheus is, which was put in after Gallus was killed by an angry Augustus). Cornelius Gallus, the first prefect in Egypt, had become too ambitious, had fallen from favour, was forced to commit suicide in 27 B.C., and suffered a posthumous damnatio memoriae. Gallus' downfall happened in 30-29 B.C., just around the time that Vergil finished the Georgics. This was obviously not the right time to sing Gallus' praises. Hermes $(1980,298)$ concludes that Servius' notes about "laudes Galli" should be considered unworthy of belief. However, it is no longer possible to check Servius' story. It is feasible that Vergil intended from the start for the epyllion to close the poem. Whatever happened to the end of the poem, as they stand, the Aristaeus epyllion and the interlude (lines 281-558) form an organic part of the whole, and show a clear expression of Vergil's views. Before I analyse it, however, I will discuss the first part of book $4^{116}$.

116 Hermes' (1980) dissertation about the issue of Vergil's putative change of book 4 contains a wide ranging discussion of the secondary literature until 1977. Hermes' $(1980,298)$ final conclusion is: "Die vollkommene Komposition des Epyllions, seine enge Verzahnung mit dem Gesamtwerk, die Unwahrscheinlichkeit von Servius' bericht über das Verfahren gegen Gallus, der fehlende Nachweis einer vorsuetonischen biographischen Tradition über Vergil als möglicher Quelle für Servius, die aufgezeigten Parallelen zu ähnlichen Berichten, all dies widerlegt die Argumentation, daß die Eigenheiten des Epyllions nur durch spätere Eingriffe, das Entstehen der Nachricht nur durch eine fundierte Quelle erklärt werden können. Solange keine neuen Indizien entgegenstehen, sind die Servius-Notizen über 'laudes Galli’ als Frucht der Erschließungstätigkeit über Leben und Werk Vergils und damit als unglaubwürdig anzusehen." (The argument, that the characteristics of the epyllion can only be explained by later interference, or that the origin of the information can only be explained by a source 
The first part of book 4 contains not just good and practical advice about beekeeping, but also interesting observations about the life of the bees. The proem is short and sets out the structure of the book in a very compact form. In the first lines (G.4.1-2), Vergil writes that the fourth book will not concern only bees and honey: PROTINUS aërii mellis caelestia dona/exsequar (Forthwith, I will describe the celestial gift of honey from heaven). The book will also concern the bees as a "nation," G.4.3-5: admiranda tibi leuium spectacula rerum/magnanimosque duces totiusque ordine gentis/ mores et studia et populos et proelia dicam (in the right order I will sing of wonderful displays of tiny acts, and charitable leaders, and the character and endeavor of a whole nation, the peoples and battles). The swarm of bees, with its many human traits, is symbolic of Vergil's "nation", enabling him to give his commentary on a number of very contemporary political issues.

The bee colony has one leader that governs the other bees and directs the work of building the hives and gathering the honey. It is interesting to see which words Vergil uses to describe the leader. In line 4 of the proem the leader is a $d u x$; in line 21 the word rex is used for the first time, is then repeated eight times in the first part of book 4, that is, until line $315^{117}$. However, there are also times when two king bees struggle for power. This is described by the poet in G.4.67-103. In G.4.67-68 we read Sin autem ad pugnam exierint - nam saepe duobus/regibus incessit magno discordia motu (If however, they have gone out for battle - for discord with great commotion has often seized two kings). Naturally, one of the two bees is the stronger one, and Vergil remarks in G.4.89-90 deterior qui uisus, eum, ne prodigus obsit,/dede neci; melior uacua sine regnet in aula (he who looked inferior, let him be killed, that he is not a burden; let the better reign in the palace without hindrance). These passages refer to the civil war: the battle described is between two king bees from one and the same beehive. The passage in the lines 89-90 refers to Octavian (melior) as the rightful victor with a justified claim for the leadership over Antony (deterior uisus). Vergil hopes that Octavian may be able to realise this claim and to create peace and order.

In the first part of the book Vergil devotes some eighty lines (149-227) to the hard work of the bees and their propagation. He refers to contemporary issues again in G.4.210-218; I interpret the passage as referring to the nature of absolute despotism

which is well founded, is contradicted by the following qualities of the epyllion: its complete composition, its close connection with the total work, the improbability of Servius' information concerning the action against Gallus, the lack of evidence of a biographical tradition before Suetonius suggesting Vergil as a possible source of Servius, and the recorded parallels with similar information. As long as no new indications emerge which would contradict the above, Servius' commentary on the 'laudes Galli' should be considered a result of fabrications of Vergil's life and work, and thus unworthy of belief). See also Thomas (1988a, 13-16).

117 Not counting caeli regem in line 152. 
in Egypt and the East ${ }^{118}$. Their king is the leader of the people and "overseer of their toils" (ille operum custos), but his authority is so weak that when he is away disorder is rife amisso rupere fidem, constructaque mella/diripuere ipsae et cratis soluere fauorum (when he has gone away, they break their fealty, and break to pieces the honey they have gathered together and take apart their honey-combs).

Thus, according to Vergil, bees are like a nation living under the authority of a strong leader. Griffin $(1979,68)$ remarks that "the bees presented him with a powerful image for the traditional Roman state, in its impersonal and collective character." The bees in the allegory present indeed many traits of collectivism, but this can just as well be interpreted as the collectivism of the people at large, common in all lands around the Mediterranean. I am inclined to read the whole passage about bee life (lines 1-227) as describing any nation and not just Roman society. Further in his essay Griffin $(1979,69)$ says: “The bees, then, with their collective virtues and their lack of individuality and art, serve as a counter-part to the old Roman character. Their patriotism and self-denial (and devotion to their 'king' is only devotion to the state and to authority, not an encouragement to emperor-worship) are admirable." Vergil is indeed not encouraging "emperor-worship," but he is expressing the view that for the Roman people (with or without "their collective virtues") the problems have become so serious that times have come to fundamentally change the status quo. He suggests that time is ripe for a strong leader, perhaps even for a monarch, and that "the traditional Roman state" has come to an end. Octavian may be a suitable candidate. In the words of Griffin $(1979,70)$ :

Only Caesar can rescue the world turned upside down, and Virgil prays desperately for his success. The reconstruction longed for in the first Georgic is, we may feel, under way by the fourth; order is being restored, and the poet becomes aware of the cost - a society efficient and admirable, but impersonal and dispassionate.

Next, we are introduced to the Aristaeus epyllion (G.4.281-558) ${ }^{119}$. First, Vergil deals with the possible disappearance or death of one's bees, and how to get a new stock in G.4.281-314. The great Arcadian master is introduced in G.4.283. His identity is revealed in line 317 as the beekeeper Aristaeus, who has lost his bees as a consequence of the anger of the gods for his attempted rape of Orpheus' wife Eurydice. After he is reconciled with the gods in lines 301-302 he is shown how to make a new swarm of bees out of a bullock. The animal is "finished off by blows, the pounded flesh decomposes

118 Cf. Harrison (2007c, 139, note 14): “The other passage at Georg. 4.211 Medus Hydaspes clearly shows similar contemporary connections given the presence of Egypt and Parthia in the same context and the topic of the absolute nature of Eastern kingship.”

119 Nadeau (1984, 59-82) pointed at the similarities between the narrative in the Aeneid and the Aristaeus epyllion. See also Conte (1986, 130-140); Harrison (2007c, 161-166); Mynors (2003, 293-323); Wilkin $\neg$ Son (1997, 108-120). 
in the unhurt hide" (plagisque perempto/tunsa per integram soluuntur uiscera pellem). When the carcass is left with thyme and fresh lavender (casia) in a damp and warm environment, bees will grow out of the cadaver. This is the art of "bougonia" (born of an ox) practiced in Egypt.

The myth of Aristaeus is not just the end to a great didactic poem, but also an allegory for Octavian and Antony, whose struggle for power had reached its height in September 31 B.C.; Vergil finished the Georgics two years later. The narrative is a functional reference to Octavian (the beekeeper), and to his adversaries Antony and Cleopatra, and perhaps also to Sextus Pompeius. The story oscillates, as it were, between Aristaeus who reminds us of Octavian and the same Aristaeus who is Antony. At the end of the story 'Octavian-Aristaeus' is the winner of the struggle for power when he assumes control over the bees, that is, the Roman state. Nadeau $(1984,59)$ follows a similar line of interpretation: "My intention is to show that the Aristaeus epyllion is an allegory for Augustus, Antony and Cleopatra, and Actium. [...], the contrast between the Statesman and the Lover: between, that is, Augustus and Antony." However, there is an important difference between his view and mine. The main contrast is not that between the statesman and the lover. The story oscillates between, on the one hand, the sense of duty of Octavian to restore order and bring peace and, on the other hand, the destructive alliance of Antony and Cleopatra ${ }^{120}$. The view that in an allegory one persona (Aristaeus) or one object may, at the same time, represent opposite qualities, or portray two different persons (Octavian's duty and Antony's passion), may strike as being rather fanciful. However, this can be found in other places too, for instance in the story of Pallas' sword belt (A.10.480-505), which Turnus takes after he killed Pallas and which symbolises his cruel exultation (A.10.500): quo nunc Turnus ouat spolio gaudetque potitus (now Turnus rejoices in the spoils, and is delighted having got possession of it). The same belt is later the cause of cruelty, when Turnus is slaughtered by Aeneas (A.12.941-949) after pleading for his life. The sword belt (the object) is a functional reference to both Turnus' emotions of elation when having killed Pallas as well as Aeneas' fury killing Turnus (A.12.947-948): tune hinc spoliis indute meorum/eripiare mihi? (you, adorned with the spoils of one of mine, you to be snatched away from me?). In other words: Turnus takes possession of the belt and is elated, but then Turnus wears the belt and is killed.

Mynors (2003, 293), discussing "the production of a fresh stock of bees from the putrefying carcass of an ox or bullock," argues (2003, 293-294) that the subject "demanded inclusion as being remarkable in itself and recognized normally in the technical literature. It was also apparently well known to the reading public, for there are frequent references to it in the poetry from the third century BC onwards." Mynors

120 Harrison (2007c, 164-167) argues that Aristaeus represents a parallel between Octavian's military career through his military victories and Vergil's poetic career "through military and nationalistic epic." 
gives several examples. I suggest that Vergil included the subject of the production of a new stock not only for the reasons Mynors mentions, but also because Vergil wants to refer to the political theme of the contrast between the sense of duty of Octavian to restore order on the one hand, and the alliance of Antony and Cleopatra on the other. In my view, a number of features of the passage from line 281 onwards suggests that Vergil was also considering contemporary issues. For instance, locating the art of "bougonia" in Egypt and the East $(G .4 .287-288,290)$ may refer to the recent war against Antony and Cleopatra and the still unresolved military problems with the Parthians (cf. Nadeau, 1984, 72-73; see also Mynors, 2003, 297). In addition, Vergil's choice of the beekeeper is significant. Mynors (2003, 294) argues that "the discoverer of the new method [of producing a new swarm] must fulfil certain conditions: he must (1) be a beekeeper," and adds the attributes this man must have. I suggest that Vergil chose a beekeeper for different reasons. It is not by chance that pastor Aristaeus, in line 317, is the answer to the question posed in line 315: Quis deus hanc, Musae, quis nobis extudit artem? (What god, Muses, found out this skill for us?). Aristaeus is Vergil's functional model for Octavian. Aristaeus, the beekeeper, is responsible for his bees in the same way as Octavian is responsible for his people: the bees symbolize the nation. The contrast Octavian-Antony can further be deduced from the following passages: G.4.317-332 (Octavian's claim to restore order), G.4.351-356 (attacks on Octavian's heritage), G.4.360 (iuvenis as a reference to Octavian), G.4.453-459 (Antony's passion for Cleopatra and her death) and G.4.554-558 (Octavian's victory). I will now focus on each passage in turn.

In G.4.317-332 Aristaeus complains bitterly to his mother Cyrene about the loss of his bees and tells her to let the rest of his work be destroyed as well. Lines 317-321 and 326-328 say:

pastor Aristaeus fugiens Peneia Tempe, amissis, ut fama, apibus morboque fameque, tristis ad extremi sacrum caput astitit amnis multa querens, atque hac adfatus uoce parentem: 'mater, Cyrene mater, [...] en etiam hunc ipsum uitae mortalis honorem, quem mihi uix frugum et pecudum custodia sollers omnia temptanti extuderat, te matre relinquo.

(The shepherd Aristaeus, fleeing from Peneian Tempe, when, as the story goes, his bees had been lost through sickness and hunger, sorrowfully stood at the sacred source of the river, and with loud lament addressed his mother with these words: "mother, mother Cyrene, [...] look, even this honour of my mortal life, that the expert care of crops and cattle had with difficulty squeezed out for me for all my endeavour, I have lost, although you are my mother)

In the Georgics the bees stand for the Roman state, and G.4.317-332 can be understood as referring to Octavian fighting for political control in Rome. Aristaeus' complaint, in lines 326-328, that his entire endeavour was of no avail refers to Octavian's claim that he be allowed to continue and to finish the work of establishing peace and order. 
After Vergil has given the names and the pursuits of the sea nymphs who are in the company of mother Cyrene, the nymph Arethusa appears in a following passage (G.4.351-354). She hears Aristaeus' "loud lament” and calls on Cyrene to pay attention.

sed ante alias Arethusa sorores

prospiciens summa flauum caput extulit unda,

et procul: 'o gemitu non frustra exterrita tanto,

Cyrene soror,

(But, before the other sisters, Arethusa with her golden head above the waves looked into the distance, and cried from afar: "o sister Cyrene, it was not without reason that you were frightened by such lament)

It is no coincidence that Vergil gave this role to Arethusa. She is a Sicilian nymph and her presence reminds readers of Octavian's shipwreck off the Sicilian coast in the war against Sextus Pompeius. The nymphs bring Aristaeus to his mother Cyrene's underwater palace. In line 360 Aristaeus is called iuvenis, a name by which Octavian was often referred to. The beekeeper duly enters the palace and is looked after by the nymphs. Cyrene decides that Proteus should be consulted. Mother and son thus depart to the cave of Proteus and watch him return home. When the seer has settled, Aristaeus approaches him to ask him why he has lost his bees. Proteus tries to avoid replying, but the pastor overwhelms him and in G.4.448-449 says to him: deum praecepta secuti/uenimus hinc lassis quaesitum oracula rebus (by the orders of the gods, we have come here to seek an oracle for my flagging circumstances). Proteus answers in G.4.453-459:

'Non te nullius exercent numinis irae;

magna luis commissa: tibi has miserabilis Orpheus

haudquaquam ob meritum poenas, ni fata resistant, suscitat, et rapta grauiter pro coniuge saeuit.

illa quidem, dum te fugeret per flumina praeceps,

immanem ante pedes hydrum moritura puella

seruantem ripas alta non uidit in herba.

("Nothing less than the anger of a god troubles you; you pay for great crimes: unhappy Orpheus evokes these punishments - by no means up to your deserts - against you, if Fate did not oppose, and he is severely angry as his wife is torn from him. She, when she rushed away from you in headlong flight along the river, she, the ill-fated girl, did not see the enormous snake amid the deep grass at her feet that inhabited the banks) ${ }^{121}$

Aristaeus is told that the gods are angry because he attempted to rape Eurydice, who died by snakebite when she ran away from him. In line 457, the story swings to a reference to Cleopatra who was believed to have died from snakebites and to "Antony-

121 In G.4.455, the OCT gives haudquaquam ob meritum poenas. As ob makes no sense, I follow the suggestion of Mynors (ad.loc.) to read $a d$. 
Aristaeus," who is reproached (line 454: magna luis commissa) for his illicit affair with Cleopatra. Vergil continues in G.4.460-527 with the story of Orpheus and Eurydice and the former's attempt to rescue her from the underworld. I interpret 4.460-527 as also alluding to Antony and Cleopatra, as their love affair was also destined to fail. The narrative continues as Proteus suddenly disappears and Cyrene tells her son to expiate himself with the gods, the nymphs and Eurydice. Aristaeus does as his mother bids him, and on the ninth day he offers his funeral dues to Orpheus. After this his bees are returned to him. In G.4.554-558 the poem reads:

hic uero subitum ac dictu mirabile monstrum

aspiciunt, liquefacta boum per uiscera toto

stridere apes utero et ruptis efferuere costis,

immensasque trahi nubes, iamque arbore summa

confluere et lentis uuam demittere ramis.

(but there they see an unexpected portent, wonderful to be told: everywhere in the belly on the putrefied flesh of the oxen, bees are buzzing and they swarm forth from the burst sides, they haul in enormous clouds, and then crowd together in a treetop hanging down in a bunch from the tough branches)

Aristaeus' new swarm of bees is the result of bougonia. If one accepts theinterpretation that the bees refer to a nation of people, the bougonia symbolizes the resurrection of the nation: the new state (the new swarm of bees) rises from a corpse (ravages of the civil war). This passage expresses the cost with which Octavian attained control of the Roman state. Therefore, these lines show Vergil's concern regarding the way the Principate had been established and the havoc it has created. The lines contain an obvious criticism. "Octavian-Aristaeus" is the eventual victor and one can see Vergil's hope that perhaps an end to the war and slaughter is in sight.

The book closes with a $\sigma \varphi \rho \alpha y i \varsigma$ (lines 559-566), in which the poet gives his name (line 563, Vergilium), an indication of the date (lines 560-561, Caesar fulminat ad Euphraten) and the place where he wrote the poem (line 564, Parthenope). Vergil was in Naples where he was enjoying life at the time that Octavian travelled through the East after Actium. The reference to Octavian is significant. Mynors (2003, 323-324) says about the epilogue:

The dating provides the excuse for a final tribute to the hero and benefactor [Octavian], who has not merely made it possible for him [Vergil] to be a poet, but by the restoration of peace and good order has given back its true meaning to the good life, the country life, of which the poem treats. And the mention of himself, modest though it purports to be, is so aptly balanced, quatrain for quatrain, against that tribute to Octavian as to take on something of the quality of a manifesto.

I agree with Mynors' view that the Georgics shows more optimism than the Eclogues. The book has indeed the character of a manifesto, but in my view a manifesto of hope and not of achievement. When Vergil finished the book in 31 or 30 B.C., peace was only just beginning. The very last line of the book - Tityre, te patulae cecini sub tegmine 
fagi (of you I sang, Tityrus, under the cover of a spreading beech) - refers to the very first line of the book of Eclogues. Vergil's self-reference expresses that the problems described in Ecl.1 have not been resolved yet ${ }^{122}$. My view differs from that of Harrison (2007c, 166) who argues that "the effect of citing the first line of the Eclogues at the end of the Georgics seems to be that of ending a phase in the Vergilian poetic career, and in the teleological transition of the Georgics towards military epic.” I consider Harrison's interpretation within the literary frame as supplementary to mine, in the sense that Vergil is making at the same time a literary and political statement: Vergil expects that in his future epic Octavian's achievements will show that many of the problems have been resolved and that a new society is emerging.

\subsubsection{Summary Of The Section About The Georgics}

The Georgics is divided into two parts, the first consisting of books 1 and 2 and the second of books 3 and 4. Book 1 is sombre in tone, emphasises hard work and ends with a catastrophe, the death of Iulius Caesar and the horror of the war which followed. Book 2 is lively and deals with lighter work. This pattern is repeated in the second part, books 3 and 4. Book 3 begins with a factual description of the care of cattle, horses and sheep, but ends with the disaster of animals dying of the plague. The last book teaches about bees and deals with the loss of the whole swarm, but ends with the positive climax of their resurrection through bougonia. The first two books are about immovables, fields and trees, while books 3 and 4 deal with animals and bees.

The proem to book 1 deals with the desolate state of farming and the sufferings of the farmers, and asks Octavian for his pity. The finale of book 2 picks up this theme and, after praising the beauty of Italia, Vergil portrays the peaceful country life of old versus the stress of modern city life. In a reference to the contemporary political situation, he deplores the destruction of traditional country life. A pattern of related themes repeats itself in the last two books. The proem of book 3 praises Caesar Octavian and his victories, among others the defeat of Cleopatra, and links the future princeps with Mantua, the poet's favourite part of Italia. In the epilogue to the whole book of the Georgics at the end of book 4 Vergil returns to this subject and lauds Octavian for his victories. He expresses his hope that the problems he set out in the very first lines of book 1 will be resolved by Octavian. Thus, Vergil places his main themes at the crucial points of the structure of the whole book: the poverty of the free farmers in Italia (proem to 1), the destruction of traditional country life (finale of 2), Octavian's victories (proem to 3), and his hope that Octavian can restore peace and

122 For a different view see Theodorakopoulos (2000, 161). See my commentary on Ecl.1 in section 3.1.2. 
order (finale of 4). The Georgics ends with virtually the same line as that which opens the book of Eclogues, subtly symbolizing the continuity of his concern about the state of the countryside: Ecl.1.1 Tityre, tu patulae recubans sub tegmine fagi, and G.4.566 Tityre, te patulae cecini sub tegmine fagi.

The teaching about the bees in G.4.1-314 also contains a powerful political message: Vergil supports Octavian's claim of the leadership over Antony's, suggesting that the Republic has come to an end, and that a monarchy should be contemplated, with Octavian as a suitable candidate. This is confirmed in the Aristaeus epyllion which refers to Antony as the man who neglected his duty and to Octavian as the future rex who can restore peace and order. 